Prepared in cooperation with the Coeur d'Alene Tribe

\title{
Coeur d'Alene Lake, Idaho: Insights Gained from Limnological Studies of 1991-92 and 2004-06
}

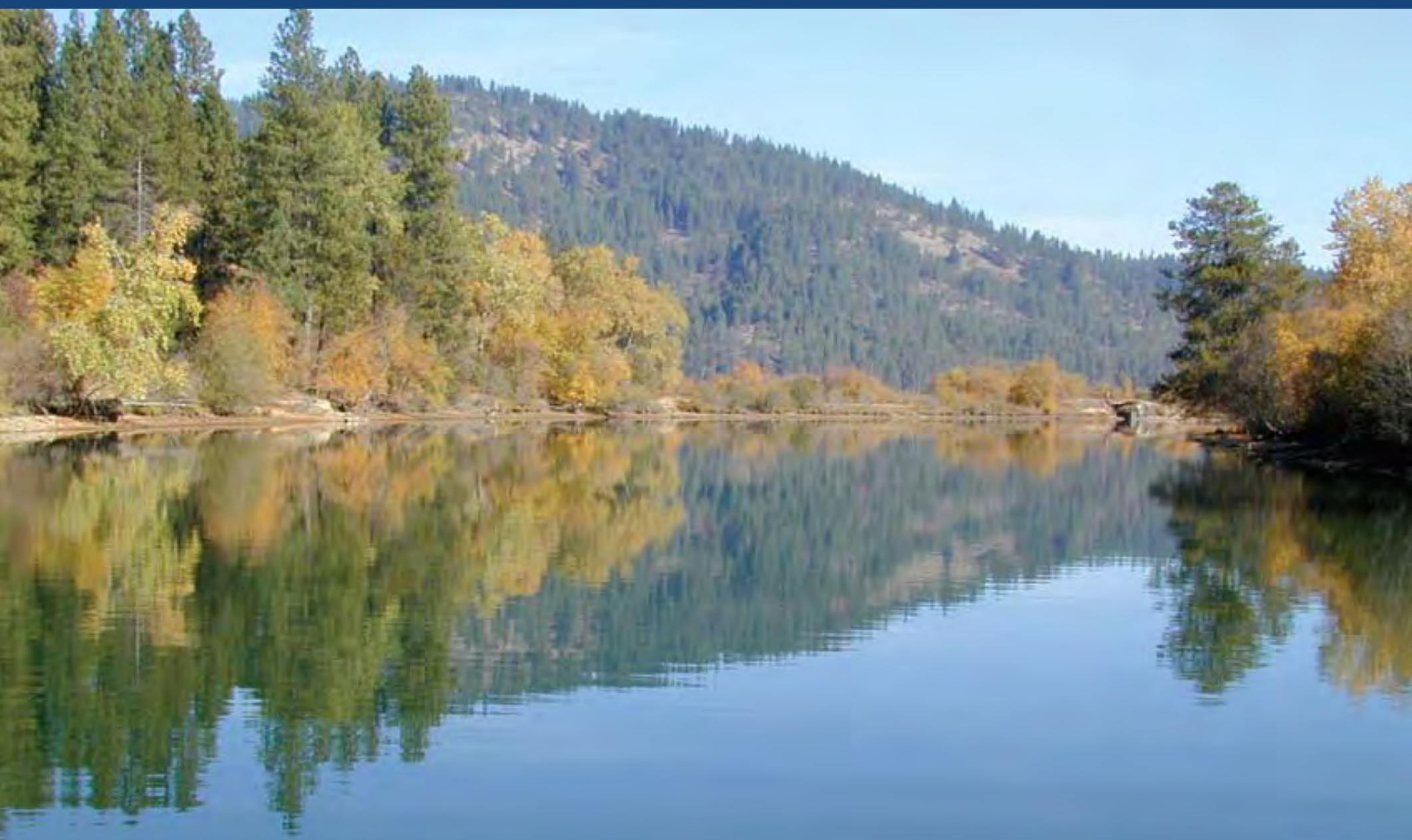

Scientific Investigations Report 2008-5168 
Cover: Coeur d'Alene Lake, northern Idaho. (Photograph taken by Paul F. Woods, U.S. Geological Survey (retired), November 1999.) 


\section{Coeur d'Alene Lake, Idaho: Insights Gained From Limnological Studies of 1991-92 and 2004-06}

By Molly S. Wood and Michael A. Beckwith

Prepared in cooperation with the Coeur d'Alene Tribe

Scientific Investigations Report 2008-5168 


\section{U.S. Department of the Interior DIRK KEMPTHORNE, Secretary}

\section{U.S. Geological Survey \\ Mark D. Myers, Director}

\section{U.S. Geological Survey, Reston, Virginia: 2008}

For product and ordering information:

World Wide Web: http://www.usgs.gov/pubprod

Telephone: 1-888-ASK-USGS

For more information on the USGS — the Federal source for science about the Earth, its natural and living resources, natural hazards, and the environment:

World Wide Web: http://www.usgs.gov

Telephone: 1-888-ASK-USGS

Any use of trade, product, or firm names is for descriptive purposes only and does not imply endorsement by the U.S. Government.

Although this report is in the public domain, permission must be secured from the individual copyright owners to

reproduce any copyrighted materials contained within this report.

Suggested citation:

Wood, M.S., and Beckwith, M.A., 2008, Coeur d'Alene Lake, Idaho-Insights gained from limnological studies of 1991-92 and 2004-06: U.S. Geological Survey Scientific Investigations Report 2008-5168, 40 p. 


\section{Contents}

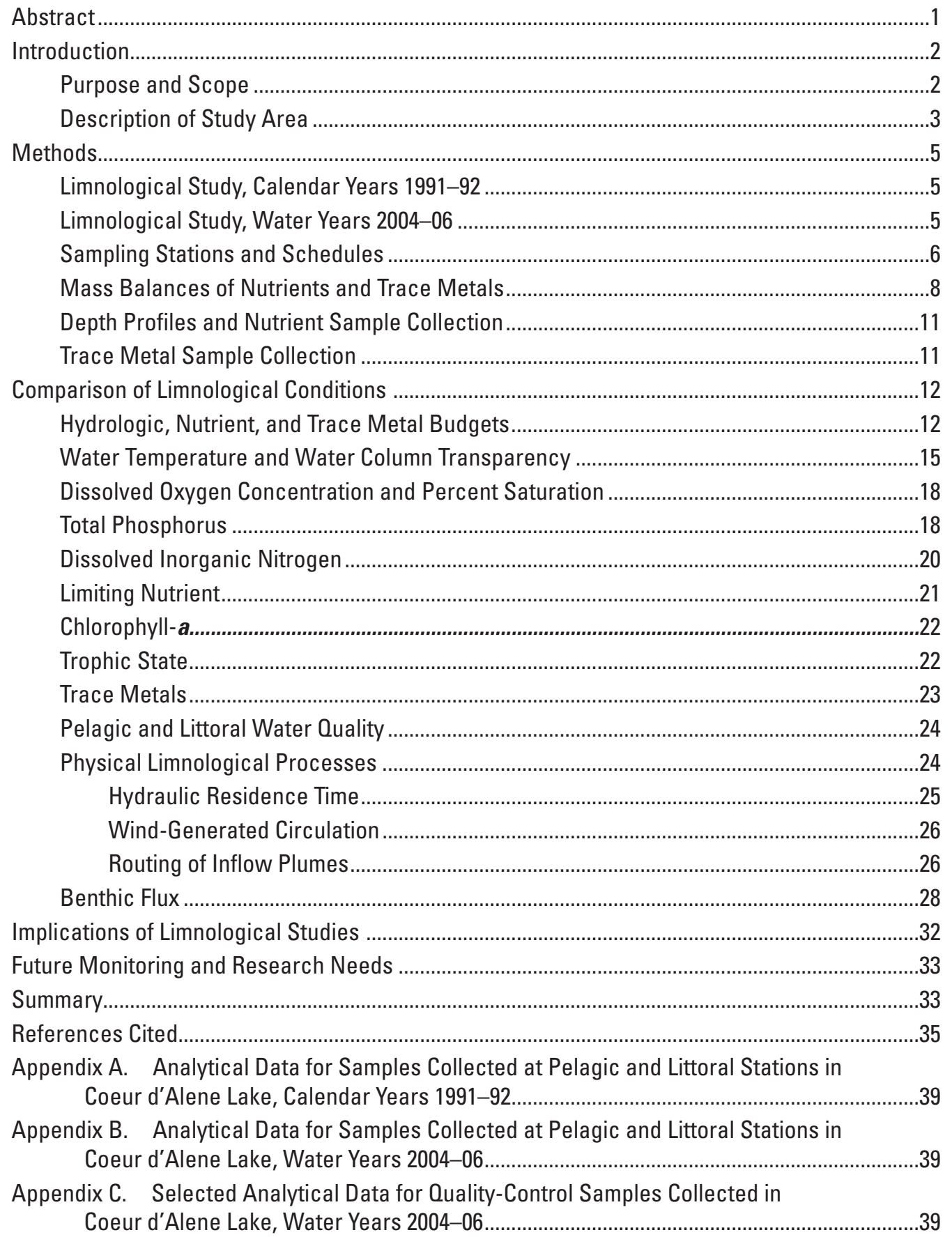




\section{Figures}

Figure 1. Map showing study area and locations of streamflow-gaging stations and littoral, benthic flux, and pelagic stations, in and near Coeur d'Alene Lake, Idaho, water years 1999 and 2004-06

Figure 2. Graph showing variation in lake stage and sampling dates at pelagic stations, Coeur d'Alene Lake, Idaho, water years 2004-06

Figure 3. Graph showing median depths of thermocline, Secchi-disc transparency, and euphotic zone at five pelagic stations, Coeur d'Alene Lake, Idaho, calendar years 1991-92 and water years 2004-06

Figure 4. Graph showing minimum and maximum percent saturation of dissolved oxygen at five pelagic stations, Coeur d'Alene Lake, Idaho, calendar years 1991-92 and water years 2004-06

Figure 5. Graph showing median concentrations of total phosphorus in the euphotic zone and hypolimnion at five pelagic stations, Coeur d'Alene Lake, Idaho, calendar years 1991-92 and water years 2004-06.

Figure 6. Graph showing median concentrations of dissolved inorganic nitrogen in the euphotic zone and hypolimnion at five pelagic stations, Coeur d'Alene Lake, Idaho, calendar years 1991-92 and water years 2004-06

Figure 7. Graph showing median concentrations of chlorophyll-a in the euphotic zone at five pelagic stations, Coeur d'Alene Lake, Idaho, calendar years 1991-92 and water years 2004-06

Figure 8. Graph showing median concentrations of total zinc in euphotic zone and hypolimnion at five pelagic stations, Coeur d'Alene Lake, Idaho, calendar years 1991-92 and water years 2004-06 


\section{Tables}

Table 1. Pelagic stations in Coeur d'Alene Lake, Idaho, common to studies in calendar years 1991-92 and water years 2004-06

Table 2. Lake characteristics for selection of limnological sampling times at five pelagic stations in Coeur d'Alene Lake, Idaho, water years 2004-06 7

Table 3. Littoral stations sampled in Coeur d'Alene Lake, Idaho, water years 2004-06. ..... 8

Table 4. Nutrient load budgets and errors, Coeur d'Alene Lake, Idaho, calendar years 1991-92 and water years 2004-06

Table 5. Selected trace-metal loads and errors measured at three gaging stations near Coeur d'Alene Lake, Idaho, calendar years 1991-92 and water years 2004-06 ..... 16

Table 6. Changes in method reporting limits for selected constituents sampled in Coeur d'Alene Lake, Idaho, calendar years 1991-92 and water years 2004-06

Table 7. Trophic state based on lake-wide median values for three limnological variables, Coeur d'Alene, Idaho, calendar years 1991-92 and water years 2004-06

Table 8. Comparisons of medians and ranges of total phosphorus, chlorophyll-a, and total zinc concentrations at pelagic and paired littoral stations on common weeks sampled, Coeur d'Alene Lake, Idaho, water years 2004-05

Table 9. Inflow plume routing based on comparison of riverine inflow temperatures and water column temperature ranges at pelagic station 3, Coeur d'Alene Lake, Idaho, water years 2004-05

Table 10. Benthic flux of dissolved metals measured by an in-situ flux chamber, Coeur d'Alene Lake, Idaho, 1999

Table 11. Benthic flux of nutrients and dissolved organic carbon measured by an in-situ flux chamber, Coeur d'Alene Lake, Idaho, 1999

Table 12. Medians and ranges of concentrations of selected constituents measured in lower hypolimnion and near sediment-water interface at pelagic station 4 , Coeur d'Alene Lake, Idaho, water years 2004-06 


\section{Conversion Factors, Datums, Abbreviations, and Acronyms}

Inch/Pound to SI

\begin{tabular}{|c|c|c|}
\hline Multiply & By & To obtain \\
\hline mile (mi) & 1.609 & kilometer $(\mathrm{km})$ \\
\hline square mile $\left(\mathrm{mi}^{2}\right)$ & 259.0 & hectare (ha) \\
\hline square mile $\left(\mathrm{mi}^{2}\right)$ & 2.590 & square kilometer $\left(\mathrm{km}^{2}\right)$ \\
\hline \multicolumn{3}{|l|}{ SI to Inch/Pound } \\
\hline Multiply & By & To obtain \\
\hline centimeter $(\mathrm{cm})$ & 0.3937 & inch (in.) \\
\hline cubic hectometer $\left(\mathrm{hm}^{3}\right)$ & $35,314,666.7$ & cubic foot $\left(\mathrm{ft}^{3}\right)$ \\
\hline cubic hectometer/year (hm³/yr) & 810.7 & acre-foot/year (acre-ft/yr) \\
\hline cubic kilometer $\left(\mathrm{km}^{3}\right)$ & 0.2399 & cubic mile $\left(\mathrm{mi}^{3}\right)$ \\
\hline cubic meter per second $\left(\mathrm{m}^{3} / \mathrm{s}\right)$ & 70.07 & acre-foot per day (acre-ft/d) \\
\hline hectare (ha) & 0.003861 & square mile $\left(\mathrm{mi}^{2}\right)$ \\
\hline kilogram (kg) & 2.205 & pound avoirdupois (lb) \\
\hline kilogram per day $(\mathrm{kg} / \mathrm{d})$ & 2.205 & pound avoirdupois per day (lb/d) \\
\hline kilogram per year $(\mathrm{kg} / \mathrm{yr})$ & 2.205 & pound avoirdupois per year (lb/yr) \\
\hline kilometer (km) & 0.6214 & mile (mi) \\
\hline liter $(\mathrm{L})$ & 33.82 & ounce, fluid (fl. oz) \\
\hline $\begin{array}{l}\text { micrograms per square centimeter } \\
\text { per year }\left(\mu \mathrm{g} / \mathrm{cm}^{2} / \mathrm{yr}\right)\end{array}$ & 0.0000002276 & $\begin{array}{l}\text { ounce, avoirdupois, per square } \\
\text { inch per year }\left(\mathrm{oz} / \mathrm{in}^{2} / \mathrm{yr}\right)\end{array}$ \\
\hline millimeter (mm) & 0.03937 & inch (in.) \\
\hline meter $(\mathrm{m})$ & 3.281 & foot $(\mathrm{ft})$ \\
\hline meter $(\mathrm{m})$ & 1.094 & yard (yd) \\
\hline square meter $\left(\mathrm{m}^{2}\right)$ & 10.76 & square foot $\left(\mathrm{ft}^{2}\right)$ \\
\hline square centimeter $\left(\mathrm{cm}^{2}\right)$ & 0.1550 & square inch $\left(\mathrm{ft}^{2}\right)$ \\
\hline square kilometer $\left(\mathrm{km}^{2}\right)$ & 247.1 & acre \\
\hline square kilometer $\left(\mathrm{km}^{2}\right)$ & 0.3861 & square mile $\left(\mathrm{mi}^{2}\right)$ \\
\hline
\end{tabular}

Temperature in degrees Celsius $\left({ }^{\circ} \mathrm{C}\right)$ may be converted to degrees Fahrenheit $\left({ }^{\circ} \mathrm{F}\right)$ as follows:

${ }^{\circ} \mathrm{F}=\left(1.8 x^{\circ} \mathrm{C}\right)+32$.

Altitude, as used in this report, refers to distance above the vertical datum.

Specific conductance is given in microsiemens per centimeter at 25 degrees Celsius $(\mu \mathrm{S} / \mathrm{cm}$ at $\left.25^{\circ} \mathrm{C}\right)$.

Concentrations of chemical constituents in water are given either in milligrams per liter (mg/L) or micrograms per liter $(\mu \mathrm{g} / \mathrm{L})$. 


\title{
Conversion Factors, Datums, Abbreviations, and Acronyms- Continued
}

\author{
Datums
}

Vertical coordinate information is referenced to the North American Vertical Datum of 1988

(NAVD 88).

Horizontal coordinate information is referenced to the North American Datum of 1983 (NAD 83) unless otherwise noted.

Abbreviations and Acronyms

\begin{tabular}{ll}
\hline $\begin{array}{l}\text { Abbreviations } \\
\text { and Acronymn }\end{array}$ \\
\hline AMLE & $\begin{array}{l}\text { Adjusted Maximum Likelihood Estimator } \\
\text { chromatographic-fluorometric }\end{array}$ \\
C-F & Comprehensive Environmental Response, Compensation and Liability Act \\
CERCLA & calendar year \\
CY & dissolved organic carbon \\
DOC & U.S. Environmental Protection Agency \\
EPA & High-Performance Liquid Chromatography \\
HPLC & Idaho Department of Environmental Quality \\
IDEQ & nitrogen-to-phosphorus ratios \\
N:P & Number Cruncher Statistical System \\
NCSS & Natural Resources Damage Assessment and Restoration \\
NRDAR & USGS National Water Quality Laboratory \\
NWQL & Operable Unit 3 \\
OU3 & photosynthetically active radiation \\
PAR & Remedial Investigation/Feasibility Study \\
RI/FS & Record of Decision \\
ROD & U.S. Geological Survey \\
USGS & Water Year \\
WY &
\end{tabular}


This page intentionally left blank. 


\title{
Coeur d'Alene Lake, Idaho: Insights Gained From Limnological Studies of 1991-92 and 2004-06
}

\author{
By Molly S. Wood and Michael A. Beckwith
}

\section{Abstract}

More than 100 years of mining and processing of metalrich ores in northern Idaho's Coeur d'Alene River basin have resulted in widespread metal contamination of the basin's soil, sediment, water, and biota, including Coeur d'Alene Lake. Previous studies reported that about 85 percent of the bottom of Coeur d'Alene Lake is substantially enriched in antimony, arsenic, cadmium, copper, lead, mercury, silver, and zinc. Nutrients in the lake also are a major concern because they can change the lake's trophic status_-or level of biological productivity - which could result in secondary releases of metals from contaminated lakebed sediments. This report presents insights into the limnological functioning of Coeur d'Alene Lake based on information gathered during two large-scale limnological studies conducted during calendar years 1991-92 and water years 2004-06.

Both limnological studies reported that longitudinal gradients exist from north to south for decreasing water column transparency, loss of dissolved oxygen, and increasing total phosphorus concentrations. Gradients also exist for total lead, total zinc, and hypolimnetic dissolved oxygen concentrations, ranging from high concentrations in the central part of the lake to lower concentrations at the northern and southern ends of the lake. In the southern end of the lake, seasonal anoxia serves as a mechanism to release dissolved constituents such as phosphorus, nitrogen, iron, and manganese from lakebed sediments and from detrital material within the water column.

Nonparametric statistical hypothesis tests at a significance level of $\alpha=0.05$ were used to compare analyte concentrations among stations, between lake zones, and between study periods. The highest dissolved oxygen concentrations were measured in winter in association with minimum water temperatures, and the lowest concentrations were measured in the Coeur d'Alene Lake hypolimnion during late summer or autumn as prolonged thermal stratification restricted mixing of the oxygenated upper water column and the hypolimnion, where oxygen was consumed. Large differences in median concentrations of dissolved inorganic nitrogen were measured between the euphotic zone and hypolimnion in the deep areas of the lake. These differences in nitrogen concentrations were attributable to several limnological processes, including seasonal inflow plume routing, isolation from wind-driven circulation and associated hypolimnetic enrichment, phytoplanktonic assimilation during summer months, and benthic flux.

Increased chlorophyll- $a$ and total phosphorus concentrations were measured throughout the lake in the 2004-06 study compared with results from the 1991-92 study. No significant change in hypolimnetic dissolved inorganic nitrogen concentration throughout the lake was noted even though total nitrogen loads into the lake decreased between study periods. Total zinc and total lead decreased throughout the lake from the 1991-92 study to the 2004-06 study except in the southern part of the lake, where concentrations were typically low. Median detected nitrogen-to-phosphorus ratios decreased from the 1991-92 study to the 2004-06 study. Whereas the lake was clearly phosphorus-limited in 1991-92, in 2004-06 the lake may have been much closer to the boundary value of 7.2 that separates nitrogen from phosphorus limitation. However, due to changes in analytical reporting limits in the period between the two studies, the data are insufficiently certain to draw reliable conclusions with regard to limiting nutrients. For both studies, the trophic state of the lake was classified as oligotrophic (less productive) or mesotrophic (moderately productive), depending on the constituent used for classification.

Internal circulation from wind-generated waves and changes in the lake's thermocline are important processes for distribution of water-quality constituents throughout Coeur d'Alene Lake. Surficial distribution of trace metals throughout most of the lake, including bays, is relatively uniform. Even south of the Coeur d'Alene River mouth, lakebed sediments are contaminated with trace metals. Inflow plume routing of the two primary inflow sources, the Coeur d'Alene and St. Joe Rivers, also significantly affects the fate and transport of contaminants. Most riverine inflows appear to move through the lake as overflow during summer, interflow during spring and autumn, and underflow during winter.

Benthic flux is another key transport process for contaminants in Coeur d'Alene Lake. The results of in situ benthic flux chamber experiments indicated movement of dissolved metals, nutrients, and dissolved organic carbon out of the lakebed sediments. However, the lake is an overall sink for these constituents when they are associated with particulate material. 


\section{Introduction}

From the late 1880s to the early 1980s, the mining district in the South Fork Coeur d'Alene River valley was among the Nation's largest producers of silver, lead, zinc, and other metals. The mining and ore-processing methods used in the "Silver Valley" to extract this wealth produced large quantities of waste material containing environmentally hazardous contaminants such as cadmium, lead, and zinc. Much of this material was discharged directly to or washed into the South Fork Coeur d'Alene River and its tributaries. The beds, banks, and floodplains of the Coeur d'Alene River, Coeur d'Alene Lake, and to a lesser extent the Spokane River, contain large quantities of metal-contaminated sediments that are transported downstream and dispersed by hydrologic processes, including through Coeur d'Alene Lake, into the Spokane River, and into the State of Washington. Large quantities of metal-contaminated sediment presently reside in the bed of Coeur d'Alene Lake that, unless removed, will require long-term management actions to maintain them in place without risk to human health and the environment. The extent and magnitude of mining associated environmental contamination throughout the South Fork and main stem Coeur d'Alene River, Coeur d'Alene Lake, and Spokane River basins has resulted in environmental cleanup ("Superfund") and Natural Resources Damage Assessment and Restoration (NRDAR) litigation actions under the Comprehensive Environmental Response, Compensation and Liability Act (CERCLA) that are among the largest, most complex, longest in duration, and costliest in the Nation. The potential for nutrient enrichment and subsequent eutrophication of Coeur d'Alene Lake also are of considerable concern because of land-use activities throughout the drainage basin and along the shoreline, as well as intensive recreational use in the lake (Woods and Beckwith, 1997). A nutrient load study conducted in 1975 as part of the National Eutrophication Survey led to the determination that Coeur d'Alene Lake was mesotrophic, or moderately productive (U.S. Environmental Protection Agency, 1977), which prompted continued observation of the lake's trophic status.

Comprehensive studies of Coeur d'Alene Lake and the surrounding watershed were conducted in the late 1980s and early 1990s by the U.S. Geological Survey (USGS) and Coeur d'Alene Tribe in cooperation with Idaho Department of Environmental Quality (IDEQ) (Woods, 1989; Horowitz and others, 1993, 1995a, 1995b; Woods and Berenbrock, 1994; Woods and Beckwith, 1997).

In 1998, the U.S. Environmental Protection Agency (USEPA) began a Remedial Investigation/Feasibility Study (RI/FS) to assess mining associated contamination outside the original $21 \mathrm{mi}^{2}$ Bunker Hill Mining and Metallurgical
Complex Superfund Site surrounding the communities of Kellogg and Smelterville, Idaho. USGS researchers were involved in the RI/FS by establishing and operating the Coeur d'Alene Basin Environmental Monitoring Program to monitor hydrological conditions and constituent concentrations and transport throughout the Coeur d'Alene River basin, and by conducting additional, highly focused limnological sampling of contaminant transport through the lake and geochemical research of contaminant flux at the sediment-water interface. In 2000, the U.S. 9th Circuit Court of Appeals ruled that the Bunker Hill Site includes all areas in the Coeur d'Alene Lake/ Spokane River basin (the Basin) where hazardous substances have come to be located. In 2002, the USEPA issued a Record of Decision (ROD) (U.S. Environmental Protection Agency, 2002) for Operable Unit 3 (OU3) of the Bunker Hill Superfund Site describing about 30 years of prioritized remedial actions for cleanup throughout the basin.

The selected remedy for OU3 did not include actions for Coeur d'Alene Lake. This decision was deferred pending the development and effective implementation of a revised Lake Management Plan to protect water quality and to effectively contain and prevent mobilization of metals from lakebed sediments. A draft Lake Management Plan was developed in June 2008 (IDEQ and Coeur d'Alene Tribe, 2008). When finalized, it will be implemented by State, tribal, Federal, and local governments outside of the formal CERCLA process using separate regulatory authorities and funding.

\section{Purpose and Scope}

This report presents insights into the limnological functioning of Coeur d'Alene Lake based on information developed from two large-scale limnological studies of the lake conducted by the USGS and the Coeur d'Alene Tribe during calendar years 1991-92 and water years 2004-06. The data collection and evaluation activities of the 2004-06 limnological studies discussed in this report were designed to provide information for the Bunker Hill Superfund Site OU3 and the Lake Management Plan (specified in the OU3 ROD to be developed and implemented instead of a formal CERCLA remedy).

The 2004-06 study included sampling and evaluation of limnological characteristics not covered by the 1991-92 study. An important goal of the 2004-06 study was to better understand the interaction of physical, chemical, and biological processes in the lake to aid in the interpretation of future water-quality trends in Coeur d'Alene Lake as remedial actions are undertaken under the OU3 ROD and the Lake Management Plan. The study design sought to evaluate the interaction of trace metals, nutrients, and lake productivity during water years 2004-06 using highly focused sampling of 
physical, chemical, and biological characteristics over a range of spatial and temporal conditions. The study's technical scope covered the following data collection and evaluation activities: (1) mass balances of trace metals and nutrients, (2) fate and transport of nutrients and quantification of lake productivity, and (3) fate and transport of trace metals.

In this report, important limnological characteristics measured by both studies are compared to gain understanding of the complex interaction of physical, chemical, and biological processes in the lake and the resulting water-quality conditions, to assess temporal and spatial differences, and to identify potential changes and trends in lake water quality over time. The insights gained from the two studies can be used in the decision-making process for managing Coeur d'Alene Lake water quality and contaminants in the basin.

\section{Description of Study Area}

Coeur d'Alene Lake-Idaho's second largest lake-is in northern Idaho (fig. 1) in the 17,300-km² Spokane River basin. The lake was created about 18,000-13,000 years ago, after a series of outburst floods from glacial Lake Missoula deposited about $100 \mathrm{~m}$ of coarse gravel deposits in the Rathdrum PrairieSpokane River Valley, damming the Pleistocene Spokane River and its two primary tributaries, the Coeur d'Alene and St. Joe Rivers (URS Greiner, Inc., and CH2M Hill, Inc., 2001). Present-day Coeur d'Alene Lake covers $129 \mathrm{~km}^{2}$ at full summer pool elevation of $649.8 \mathrm{~m}$ (NAVD 88) and is about $35-\mathrm{km}$ long in a north-south orientation. The maximum width is about $3.7 \mathrm{~km}$, and the maximum depth is about $64 \mathrm{~m}$. The volume is $2.8 \mathrm{~km}^{3}$ at full pool (Woods and Berenbrock, 1994).

The southern end of the lake, under Tribal jurisdiction, is contiguous with four shallow lakes (Benewah, Chatcolet, Hidden, and Round Lakes) that were primarily emergent wetlands prior to the 1906 construction of Post Falls Dam on the Spokane River downstream of the lake outlet. Dam operation provides storage for hydroelectric power generation by maintaining the lake surface elevation approximately 2.1-m higher than normal, following spring runoff, through late summer as the lake recedes. By delaying lake recession until late summer or early autumn, dam operation has created large expanses of shallow open water areas, increased habitat for aquatic macrophyte growth, and altered the natural levees, lateral lakes, and wetlands ecosystems in the lower reaches of the Coeur d'Alene and St. Joe Rivers.

The drainage area of Coeur d'Alene Lake is about $9,690 \mathrm{~km}^{2}$; most (90 percent) of the lake's inflow is delivered by the Coeur d'Alene and St. Joe Rivers (Woods and Beckwith, 1997). Coeur d'Alene Lake outflows to the Spokane River, a tributary of the Columbia River. The drainage area of the lake is comprised mostly of mountains covered in coniferous forests and deep, intermontane valleys. The Coeur d'Alene and St. Joe Rivers originate in the Coeur d'Alene and St. Joe Mountains, respectively, which are sub-ranges of the Bitterroot Mountains that form the IdahoMontana border. Elevations range from about $650 \mathrm{~m}$ (NAVD 88) near the lake outlet to about 2,090 m (NAVD 88). About 78 percent of the land cover in the drainage area is forest (coniferous, sparse, or recovering harvest), and rangeland and agriculture account for about 7 and 5 percent, respectively. The remaining 10 percent of the land cover, in order of largest to smallest area, is clear cut/barren land, small water bodies, wetlands, and urban and mine areas.

Annual precipitation in the drainage basin is higher than other areas in Idaho. Snowfall between October and April comprises about 70 percent of the annual precipitation. The influence of Pacific Maritime conditions can produce large rain-on-snow events during winter. The mountainous topography of the basin affects the spatial distribution of precipitation. For example, mean annual precipitation is about $64 \mathrm{~cm}$ at the lake, whereas mean annual precipitation is about $97 \mathrm{~cm}$ at Wallace, Idaho, a town in the drainage basin, which is about $75 \mathrm{~km}$ east and 250-m higher in elevation than the lake. Ambient temperature varies similarly, and although winter temperatures at Coeur d'Alene Lake often are below freezing, the lake does not typically freeze except at the shallow southern end.

The Coeur d'Alene River (drainage area 3,810 km²) discharges into the southern one-third of the lake near Harrison, Idaho, and is comprised of three major reaches: the North Fork, the South Fork, and below the confluence of the North and South Forks (not shown in figures). Primary land-use activities in the North Fork drainage basin include recreation, forestry, and agriculture, with limited historical placer and hard-rock mining. Extensive hard-rock mining, ore processing, and transportation activities occurred in the South Fork Coeur d'Alene River drainage basin. Known as the "Silver Valley", the South Fork basin was among the Nation's largest producers of silver, lead, and zinc for almost a century; currently, it includes one of the Nation's largest Superfund sites with only limited mining and ore processing. The St. Joe River (drainage area 4,520 $\mathrm{km}^{2}$ ) discharges into the extreme southern end of the lake, several miles downstream of the confluence of the St. Joe and St. Maries Rivers near St. Maries, Idaho. Recreation, forestry, and agriculture are the dominant land uses in the St. Joe River drainage area, and little mining activity has occurred. Urban land use is relatively low (less than 1 percent as of 1997) in the St. Joe and St. Maries River basins (Woods and Beckwith, 1997). However, considerable population growth and land development is occurring near the lake, including several proposed golf resort communities and marinas. 


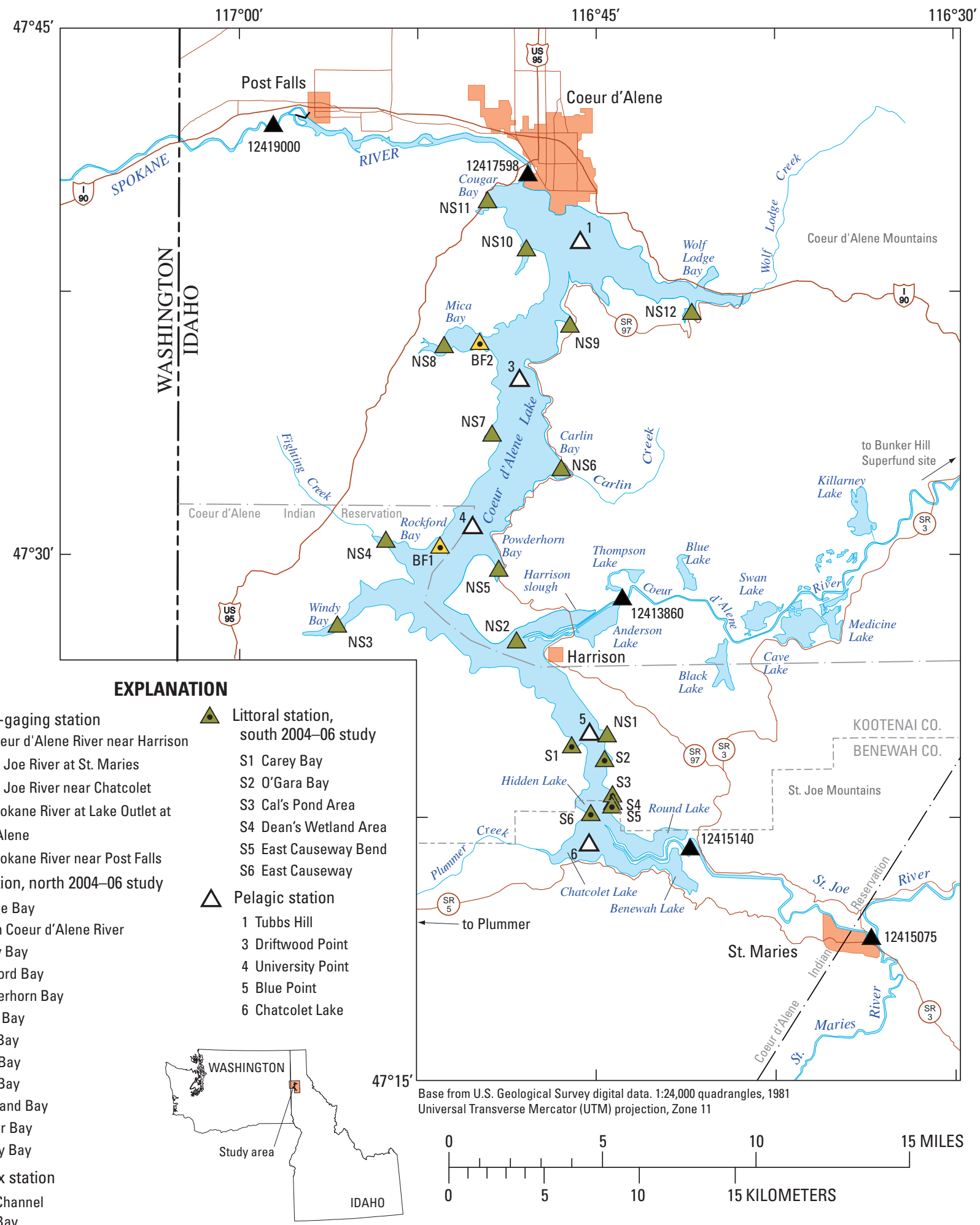

Figure 1. Study area and locations of streamflow-gaging stations and littoral, benthic flux, and pelagic stations, in and near Coeur d'Alene Lake, Idaho, water years 1999 and 2004-06. 


\section{Methods}

\section{Limnological Study, Calendar Years 1991-92}

The 1991-92 study was conducted during 2 calendar years, beginning in mid-January 1991 and ending in midDecember 1992. Seven pelagic stations were sampled every 3 weeks from May through October and every 4 to 6 weeks during the remaining months. Pelagic stations were located in the open water, deeper (10 $\mathrm{m}$ or more) areas of the lake. A full description of the sampling design and rationale for the 1991-92 study is provided in Woods and Beckwith (1997).

Full-depth profiles of water column temperature, specific conductance, $\mathrm{pH}$, and dissolved oxygen concentration and percent saturation were measured. Secchi-disc transparency depth was measured and the euphotic zone depth was determined based on water column profiles of photosynthetically active radiation (PAR) intensity. Within the euphotic zone, a composite sample was derived from three point samples that were collected with a non-metallic Van Dorn bottle. Two additional point samples were collected at mid-depth and $1 \mathrm{~m}$ above the lakebed. These water samples were analyzed for concentrations of total phosphorus, dissolved orthophosphate, total organic plus ammonia nitrogen, dissolved ammonia, and dissolved nitrite plus nitrate. Chlorophyll- $a$ was determined for the euphotic zone composite samples. On alternating sampling trips, euphotic zone and near-bottom samples were analyzed for total recoverable concentrations of arsenic, cadmium, copper, lead, mercury, and zinc. The water samples were analyzed at the USGS National Water Quality Laboratory (NWQL).

Comparisons of pelagic (open water) and littoral zone (near shore) water quality were made on two occasions and were based on 2-m-deep littoral zone samples and euphotic zone composite samples from the pelagic stations. During September 1991, 20 littoral and 6 pelagic stations were sampled concurrently for nutrients, chlorophyll- $a$, and dissolved oxygen. During August 1992, 15 littoral and 6 pelagic stations were sampled concurrently for those same variables plus total zinc. Littoral zone sampling on both occasions covered stations throughout the lake (Woods and Beckwith, 1997).

No records could be located for quality assurance/quality control samples collected during the 1991-92 study. Therefore, no assessment could be made to determine if equipment decontamination procedures were adequate to remove analytes of interest or to quantify variability introduced during sample processing and analysis.

\section{Limnological Study, Water Years 2004-06}

Samples were collected by USGS crews at five stations in the pelagic zone (fig. 1; also sampled during 1991-92), eight times each year during water years 2004-06. A water year is from October 1 through September 30. As in the 1991-92 limnological study, full-depth profiles of the water column temperature, specific conductance, $\mathrm{pH}$, and dissolved oxygen concentration and percent saturation were measured. Secchidisc transparency depth was measured, and the euphotic zone depth was determined with water column profiles of PAR intensity. Within the euphotic zone, a composite sample was collected using a pump sampler lowered through the euphotic zone. Additional point samples were collected at depths representing the upper hypolimnion and $1 \mathrm{~m}$ above the lakebed representing the lower hypolimnion. Water samples were analyzed at the USGS NWQL.

Coeur d'Alene Tribe crews collected samples at 12 stations in the littoral zone on 4 occasions in water year 2004 and at 18 stations on 4 occasions in water year 2005 and early in 2006. These sites were primarily near the heads of bays, in water about 4-m deep, and generally within $20 \mathrm{~m}$ of the lakeshore (fig. 1). Point samples were collected from a depth of $2 \mathrm{~m}$, where temperature, specific conductance, $\mathrm{pH}$, and dissolved oxygen concentration and percent saturation also were measured. Coeur d'Alene Tribe crews sampled the littoral stations during the same week that USGS crews sampled the pelagic stations. Littoral zone samples were shipped by USGS to the NWQL for analyses.

Comparisons of pelagic and littoral zone water quality were made on two occasions and were based on 2-m-deep littoral zone samples and euphotic zone composite samples from the pelagic stations. During August 2004, 12 littoral and 5 pelagic stations were sampled concurrently for nutrients, chlorophyll-a, and metals. During July 2005, 18 littoral and 5 pelagic stations were sampled concurrently for the same variables.

Quality assurance/quality control samples were collected during routine sampling trips. Field blank samples were submitted to the NWQL at a frequency of 4 percent to assess whether equipment decontamination procedures were adequate to remove analytes of interest. Three source solution blanks were submitted to assess possible contamination in blank water used in the field blank samples. Duplicate or replicate samples were submitted at a frequency of 5 percent to assess variability introduced during sample processing and analysis.

The 2004-06 study approach was designed to complement previous limnological studies of the lake that were done mostly by the USGS since 1987 (Woods, 1989; Horowitz and others, 1993, 1995a, 1995b; Woods and Berenbrock, 1994; Woods and Beckwith, 1997; Balistrieri, 1998; Kuwabara and others, 2000; Woods, 2004). The study approach also incorporated important new limnological information obtained from the RI/FS of the lake conducted by the USGS for USEPA during 1999 in support of the Bunker Hill Superfund Site OU3 ROD (URS Greiner, Inc., and CH2M Hill, Inc., 2001; CH2M Hill, Inc., and URS Corp., 2001).

The RI/FS (URS Greiner, Inc., and CH2M Hill, Inc., 2001) and a USGS evaluation (funded by the National Water Quality Assessment Program) of fate and transport processes 
in Coeur d'Alene and Pend Oreille Lakes in northern Idaho and Flathead Lake in northwestern Montana (Woods, 2004) reported that lake hydrodynamics and riverine inflow plume routing played important roles in the fate and transport of constituents and, by extension, water-quality conditions in the lakes. Therefore, limnological data collection in Coeur d'Alene Lake during water years 2004-06 was scheduled during important periods related to lake hydrodynamics and limnological conditions.

The approaches used for the two studies were similar in many respects and allowed for robust comparisons between most analytes. Two differences in approach merit further discussion: (1) compositing of euphotic zone samples, and (2) analytical methods for determination of chlorophyll- $a$ concentrations.

Water-quality profiling instrumentation used in the 2004-06 study provided high resolution (less than 0.1 $\mathrm{m})$ data that revealed substantial variations in constituent concentrations within the euphotic zone, especially during periods of thermal stratification. This variability was represented in the pumped-sample compositing used in the 2004-06 study. The 3-point sample compositing used in the 1991-92 study was less likely to have obtained a representative sample of the euphotic zone.

Concentrations of chlorophyll- $a$ for the 1991-92 study were determined with High-Performance Liquid Chromatography (HPLC) using methods from Britton and Greeson (1989). Prior to the start of the 2004-06 study, however, the USGS NWQL replaced the HPLC method with a chromatographic-fluorometric (C-F) method, presented in U.S. Geological Survey National Water Quality Laboratory (2000) and Britton and Greeson (1989). Reasons for the change in analytical methods were provided by U.S. Geological Survey, National Water Quality Laboratory, written commun., 2005. This change presented potential difficulties in comparing concentrations of chlorophyll-a between the two studies. The approach presented in this report to quantify differences between the two methods relied on the results of a NWQL comparability study where results of the two methods could be correlated through a regression equation (R. Brenton and P. Soliven, U.S. Geological Survey, written commun., October 1995). The regression equation reported in the NWQL study was derived from 39 paired samples and had the following form, with a coefficient of determination of 0.771 :

$$
(C-F)=0.45801+0.92047(\text { HPLC })
$$

where:

$\mathrm{C}-\mathrm{F}$ is chlorophyll- $a$ concentration, in micrograms per liter, determined with the C-F method, and

HPLC is chlorophyll- $a$ concentration, in micrograms per liter, determined with the HPLC method.
Equation 1 indicated that C-F values of 1.4, 5.1, and 18, respectively, were associated with HPLC values of 1.0, 5.0, and 19.

In conjunction with the work described in this report, a lake process simulation model called ELCOM-CAEDYM was developed for Coeur d'Alene Lake by the Centre for Water Research of the University of Western Australia under a cooperative agreement with the USGS and IDEQ. The goal of the model development was to provide agencies involved with the lake management decision process with a sophisticated tool to simulate lake response to a wide range of mining associated contaminant remediation and nutrient management strategies likely to occur or be proposed under the Bunker Hill Superfund Site OU3 ROD and Lake Management Plan. A detailed description of the model that was adapted to Coeur d'Alene Lake is available at http://www.cwr.uwa.edu.au (Hipsey and others, 2006). The USGS limnological studies of 1991-92 and 2004-06 were primary data sources for the application of the model to Coeur d'Alene Lake.

\section{Sampling Stations and Schedules}

Pelagic zone sampling was conducted at five stations common to the 1991-92 and 2004-06 studies (fig. 1; table 1). Stations are identified by number as $1,3,4,5$, and 6 . These stations have been sampled historically by USGS (Woods and Beckwith, 1997), IDEQ (G.F. Harvey, Idaho Department of Environmental Quality, written commun., 2000), and the USEPA during the RI/FS (URS Greiner, Inc., and CH2M Hill, Inc., 2001). Representative lake volumes were assigned to each pelagic station by digitizing a bathymetric map of the lake, developing area polygons by joining midpoints of lines drawn between stations, and calculating lake volume under each polygon footprint. According to this method, the total lake volume represented by each station is: station 1 , 27 percent; station 3, 34 percent; station 4, 34 percent; station 5, 4 percent; and station 6, 1 percent. Although stations 5 and 6 together represent only 5 percent of the lake volume, they are important because they characterize the southern end of the lake, which is more productive than other parts of the lake. Water quality in this area is determined mostly by the St. Joe River inflow. Station 6 provides a reference condition for metals concentrations, which when detected, typically are low.

Limnological samples were collected at the five pelagic stations eight times each year during water years 2004-06. Timing of sample collection reflects temporal patterns associated with lake hydrodynamics, nutrients, lake productivity, and fate and transport of trace metals and nutrients (table 2). Dates of sample collection at pelagic station 4 (representative of the other four stations) and lake stage during water years 2004-06 are shown in figure 2. 
Table 1. Pelagic stations in Coeur d'Alene Lake, Idaho, common to studies in calendar years 1991-92 and water years 2004-06.

[Station locations are shown in figure 1. Latitude, longitude in degrees, minutes, seconds, North American Datum of 1983. Depth: Lake surface at full-pool elevation of 649.8 meters (North American Vertical Datum of 1988). Abbreviations: m, meter; mi, mile]

\begin{tabular}{cllc}
\hline $\begin{array}{c}\text { Station } \\
\text { No. }\end{array}$ & \multicolumn{1}{c}{ Station location } & Latitude, longitude & $\begin{array}{c}\text { Depth } \\
\text { (m) }\end{array}$ \\
\hline 1 & 1.3 mi southeast of Tubbs Hill, near Coeur d'Alene & $47^{\circ} 39^{\prime} 00^{\prime \prime}, 116^{\circ} 45^{\prime} 30^{\prime \prime}$ & 42.5 \\
3 & 0.8 mi southwest of Driftwood Point, near Coeur d'Alene & $47^{\circ} 35^{\prime} 00^{\prime \prime}, 116^{\circ} 48^{\prime} 20^{\prime \prime}$ & 52.0 \\
4 & 1.7 mi northeast of University Point, near Harrison & $47^{\circ} 30^{\prime} 54^{\prime \prime}, 116^{\circ} 50^{\prime} 06^{\prime \prime}$ & 40.0 \\
5 & Northeast of Blue Point, near Harrison & $47^{\circ} 25^{\prime} 00^{\prime \prime}, 116^{\circ} 45^{\prime} 00^{\prime \prime}$ & 16.5 \\
6 & Chatcolet Lake, 0.4 mi northwest of Rocky Point, near Plummer & $47^{\circ} 21^{\prime} 20^{\prime \prime}, 116^{\circ} 45^{\prime} 10^{\prime \prime}$ & 11.0 \\
\hline
\end{tabular}

Table 2. Lake characteristics for selection of limnological sampling times at five pelagic stations in Coeur d'Alene Lake, Idaho, water years 2004-06.

[Lake characteristics: Related to hydrodynamics, nutrients and productivity, fate and transport of trace elements]

\begin{tabular}{|c|c|c|}
\hline Month & Sample collection & Lake characteristics \\
\hline December & No & Similar to November, but cooler temperatures. \\
\hline $\begin{array}{l}\text { January } \\
\quad \text { (late month) }\end{array}$ & Yes & $\begin{array}{l}\text { Inverse stratification, stable pool, low productivity, dissolved oxygen replenishment, circulation } \\
\text { of nutrients and trace elements, follows several months of zinc-rich inflows from Coeur } \\
\text { d'Alene River. }\end{array}$ \\
\hline February & No & $\begin{array}{l}\text { Similar to January, but rain-on-snow events may have raised elevation and input nutrients and } \\
\text { trace elements. }\end{array}$ \\
\hline March & No & Similar to February. \\
\hline $\begin{array}{l}\text { April } \\
\text { (mid-month) }\end{array}$ & Yes & $\begin{array}{l}\text { Pre-snowmelt runoff conditions, assess distribution of dissolved oxygen, nutrients, and trace } \\
\text { elements at end of winter conditions. }\end{array}$ \\
\hline $\begin{array}{l}\text { June } \\
\text { (mid-month) }\end{array}$ & Yes & $\begin{array}{l}\text { Thermally stratified, stable summer pool, increasing productivity, start of dissolved oxygen } \\
\text { depletion, increased stratification of nutrients and trace elements. }\end{array}$ \\
\hline $\begin{array}{l}\text { July } \\
\text { (mid-month) }\end{array}$ & Yes & Similar to June, but stronger stratification and dissolved oxygen depletion. \\
\hline $\begin{array}{l}\text { August } \\
\text { (mid-month) }\end{array}$ & Yes & Similar to July. \\
\hline September & No & Similar to August but start of drawdown cycle. \\
\hline
\end{tabular}

Littoral zone sampling locations were not identical for the 1991-92 and 2004-06 studies. Two sets of stations were used for sampling during 2004-06. During water years 2004-06, 12 stations representative of bays throughout the lake (identified as “NS") were sampled 4 times each year. In water year 2005, 6 additional stations were sampled in the southern end of the lake near seeps (identified as "S”) to assess trace-metal contamination adjacent to a former mining industry railroad upstream of the lake. Station locations and sample dates for the 18 littoral stations are listed in table 3 and shown in figure 1. Most littoral zone samples were collected at the 2-m depth in water columns that were about 4-m deep and within about $20 \mathrm{~m}$ of the shoreline. 


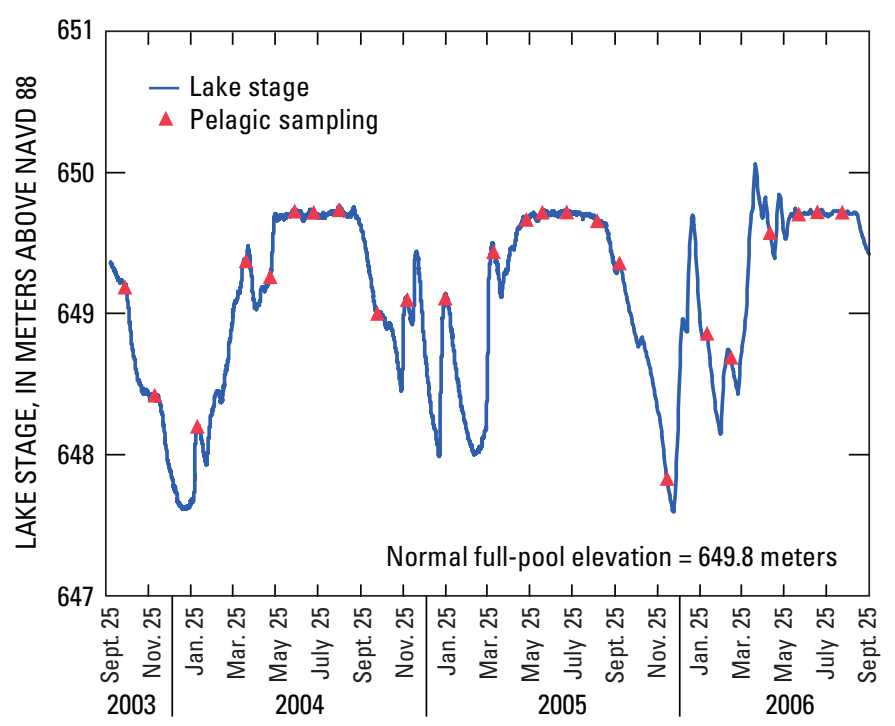

Figure 2. Variation in lake stage and sampling dates at pelagic stations, Coeur d'Alene Lake, Idaho, water years 2004-06.

\section{Mass Balances of Nutrients and Trace Metals}

The evaluation of nutrient and trace metal mass balance in this report was based on annual values derived from constituent load information generated for five USGS streamflow-gaging stations in Idaho: Coeur d'Alene River near Harrison (12413860); St. Joe River at St. Maries (12415075); St. Joe River near Chatcolet (12415140); Spokane River at Lake Outlet at Coeur d'Alene (12417598); and Spokane River near Post Falls (12419000) (fig. 1). Periodic hydrograph-based monitoring at the five gaging stations provided streamflow and concentration data required for load calculations. The 1991-92 study reported annually based hydrologic, nutrient, and trace metal budgets for Coeur d'Alene Lake (Woods and Beckwith, 1997). Three major differences between the 1991-92 and 2004-06 studies were: (1) additional constituents were measured in the 1991-92 study, and some common constituents had different method reporting limits in the 2004-06 study, (2) loads for the 1991-92 study published in Woods and Beckwith (1997) were calculated using the computer program FLUX (Walker, 1996) and loads for the 2004-06 study were calculated

Table 3. Littoral stations sampled in Coeur d'Alene Lake, Idaho, water years 2004-06.

[Station locations are shown in figure 1. Station No.: NS, nearshore; S, seep. Latitude, longitude: degrees, minutes, seconds, North American Datum of 1983]

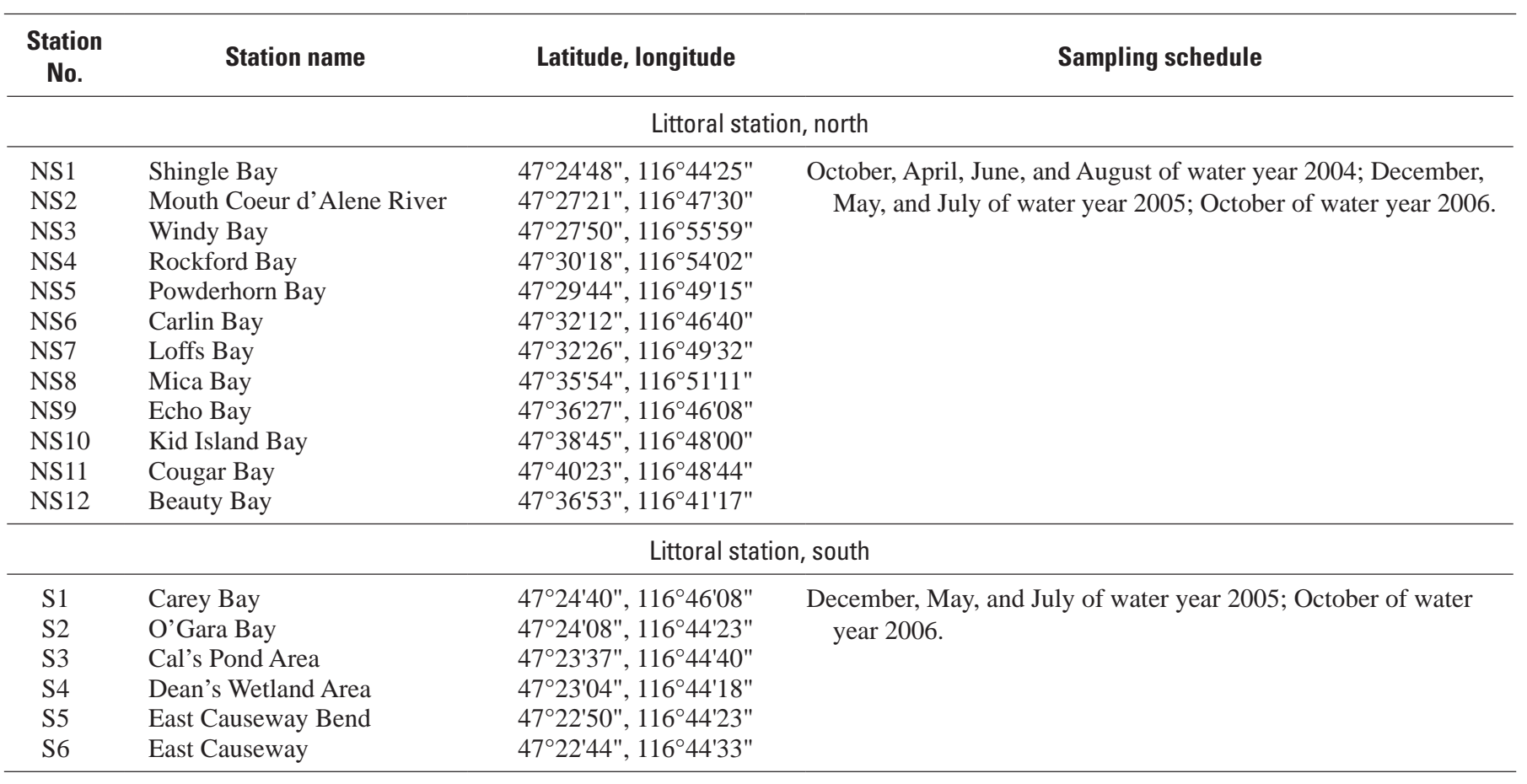


using the computer program LOADEST (Runkel and others, 2004), and (3) sampling locations changed on the St. Joe and Spokane Rivers between studies. For this report, only loads measured in common between the two studies were compared. The accuracy of the load budgets is affected by changes in method reporting limits after the NWQL updated analytical procedures in the late 1990s, and a robust direct comparison cannot be made for all constituents. The 1991-92 loads were recalculated using LOADEST so a proper comparison could be made with the 2004-06 loads. The LOADEST program uses a multiple linear regression approach to calculate loads based on available streamflow records, decimal time, seasonality functions, and other user-input explanatory variables (Runkel and others, 2004). The Adjusted Maximum Likelihood Estimator (AMLE) regression model in the LOADEST program was used to incorporate censored data with multiple reporting limits.

The gaging station on the St. Joe River was moved from St. Maries (12415075) to Chatcolet (12415140) between the 1991-92 and 2004-06 studies to capture total inflow to the lake from the St. Joe River. The station sampled during the 1991-92 study, 12415075, did not capture nutrient inputs from the St. Maries wastewater treatment plant because it was upstream of the plant outfall. Similarly, the gaging station on the Spokane River was moved from Post Falls (12419000) to Coeur d'Alene (12417598) between the 1991-92 and 2004-06 studies to quantify water-quality conditions at the primary outlet of the lake. Water-quality conditions at the station sampled in 1991-92, 12419000, were influenced by nutrients in effluent from the Coeur d'Alene, Hayden, and Post Falls municipal wastewater treatment plants. The gaging station sampled in 2004-06, 12417598, was upstream of these plant outfalls. The location of the gaging station on the Coeur d'Alene River, 12413860, remained constant between the study periods.

Nutrient load data for the Spokane and St. Joe Rivers in the 1991-92 study period were normalized to locations sampled during the 2004-06 study period for comparison of loads. Nutrient loads contributed by wastewater effluent were subtracted from the 1991-92 loads measured at station 12419000, Spokane River near Post Falls, to obtain a measure of nutrient loads at the lake outlet. Similarly, nutrient loads from wastewater effluent were added to the 1991-92 loads measured at station 12415075, St. Joe River at St. Maries. Trace metal loads were not normalized for sampling location because no data were available for computing additional inputs or losses, if any, between the sampling locations on the Spokane and St. Joe Rivers. Additional inputs or losses between sampling locations for trace metal loads are assumed to be negligible.
Total nitrogen and total phosphorus loads in effluent from the St. Maries wastewater treatment plant to the St. Joe River in 1991-92 were reported as 3,720 kg/yr and 1,400 kg/ yr, respectively, in Woods and Beckwith (1997). Average monthly loads for total phosphorus in wastewater effluent to the Spokane River were calculated from records provided by the Coeur d'Alene and Hayden municipal wastewater treatment plants. Average monthly loads for total nitrogen effluent were calculated for the Coeur d'Alene plant. Nitrogen compounds were not monitored in effluent from the Hayden plant during 1991-92; therefore, records were not available for calculation of nitrogen loads. Nutrient inputs from the Hayden plant were small compared to nutrient inputs from the Coeur d'Alene plant, and wastewater effluent was discharged to a land application site, not directly to the Spokane River, for most months in 1991-92. Consistent monitoring records were not available for the Post Falls wastewater treatment plant in 1991-92, but the plant discharged to the Spokane River yearround during the 1991-92 study period (Mark Barkley, City of Post Falls, oral commun., July 2008). Therefore, nutrient loads from the Post Falls treatment plant were estimated by multiplying nutrient loads from Coeur d'Alene treatment plant effluent by a ratio between the populations of Coeur d'Alene and Post Falls in 1991-92, according to the following equation:

PF WWTP nutrient load

$$
\begin{aligned}
& =\mathrm{CdA} \text { WWTP nutrient load } \\
& \times(\mathrm{PF} \text { population/CdA population }),
\end{aligned}
$$

where

PF WWTP nutrient load is the estimated total monthly nutrient (nitrogen or phosphorus) load in Post Falls wastewater treatment plant effluent, in kilograms;

CdA WWTP load is the measured total monthly nutrient (nitrogen or phosphorus) load in Coeur d'Alene wastewater treatment plant effluent, in kilograms; and

PF and CdA populations are the population estimates for the cities of Post Falls and Coeur d'Alene, respectively, for 1991 and 1992, according to the U.S. Census Bureau (2000), in number of people. 
Annual loads of nutrients from ungaged surface-water inflows, including Plummer, Fighting, Carlin, and Wolf Lodge Creeks, were measured during the 1991-92 study and reported in Woods and Beckwith (1997). Ungaged surface-water inflows were not sampled during the 2004-06 study; however, nutrient concentrations in inflows from these ungaged inflows were assumed to be relatively constant between the 1991-92 studies because nutrient sources in these tributaries primarily are agricultural and natural sources, not municipal wastewater treatment plant effluent. Nutrient loads in ungaged surfacewater inflows in the 2004-06 study were estimated for Plummer, Fighting, Carlin, and Wolf Lodge Creeks as well as for other ungaged surface water including small tributaries and runoff. Nutrient coefficients were calculated by relating the measured 1991 and 1992 nutrient load in a particular creek to the measured flow volume in the nearest gaged inflow, the Coeur d'Alene or St. Joe Rivers, for the same year. The 1991 and 1992 nutrient coefficients then were averaged. Inputs from "other" ungaged surface water inflows were related to the combined flow of the Coeur d'Alene and St. Joe Rivers as the exact locations of these sources are unknown. The equation for the average nutrient coefficient for ungaged surface-water inflows had the following form:

$$
\mathrm{C}_{\text {avg }}=\left(\left(\mathrm{L}_{91} / \mathrm{Q}_{\text {near91 }}\right)+\left(\mathrm{L}_{92} / \mathrm{Q}_{\text {near92 }}\right)\right) / 2 \text {, }
$$

where:

$$
\begin{gathered}
\mathrm{C}_{\text {avg }} \text { is the average nutrient (nitrogen or phosphorus) } \\
\text { coefficient for a given ungaged surface water } \\
\text { inflow, in kilograms per cubic hectometer; }
\end{gathered}
$$

$\mathrm{L}_{91}$ is the total nutrient (nitrogen or phosphorus) load for a given ungaged surface water inflow in the 1991 study, in kilograms;

$\mathrm{Q}_{\text {near91 }}$ is the total flow volume of the gaged surface-water inflow, the Coeur d'Alene or St. Joe River, closest to the ungaged surface-water inflow in the 1991 study, in cubic hectometers;

$\mathrm{L}_{92}$ is the total nutrient (nitrogen or phosphorus) load for a given ungaged surface water inflow in the 1992 study, in kilograms; and

$\mathrm{Q}_{\text {near92 }}$ is the total flow volume of the closest gaged surface-water inflow in the 1992 study, in cubic hectometers.

The average nutrient coefficient from the 1991-92 study was then used to estimate loads from ungaged surface-water inflows for each year during the 2004-06 study according to the following equation:

$$
\mathrm{L}=\mathrm{C}_{\text {avg }} \times \mathrm{Q}_{\text {near }},
$$

where:

$\mathrm{L}$ is the estimated total annual nutrient (nitrogen or phosphorus) load for a given ungaged surface water inflow for a given year in the 2004-06 study, in kilograms;

$\mathrm{C}_{\mathrm{avg}}$ is the average nutrient coefficient for a given ungaged surface water inflow, in kilograms per cubic hectometer; and

$\mathrm{Q}_{\text {near }}$ is the total flow volume of the gaged surface-water inflow, the Coeur d'Alene or St. Joe River, closest to the ungaged surface-water inflow for a given year in the 2004-06 study, in cubic hectometers.

Annual nutrient loads from precipitation and other atmospheric sources in the 1991-92 study were estimated and published in Woods and Beckwith (1997) based on data presented by Stanford and others (1983), Hallock and Falter (1987) and National Atmospheric Deposition Program (1991). These values were assumed to be constant for the 2004-06 study. Annual nutrient loads from private and community wastewater-treatment systems in the nearshore area of the lake were estimated for the 1991-92 study and published in Woods and Beckwith (1997). These values also were assumed to be constant for the 2004-06 study because no recent data were available.

Annual nutrient loads leaving Coeur d'Alene Lake in ground-water outflow to the Rathdrum Prairie aquifer were computed by multiplying the estimated ground water outflow volume, in cubic hectometers, by the mean nutrient concentration, in micrograms per liter, in the lower hypolimnion of the northern end of Coeur d'Alene Lake. Ground water outflow volume was estimated and reported as 205 cubic hectometers per year for the 1991-92 study in Woods and Beckwith (1997) and was assumed to be constant for the 2004-06 study. The mean annual concentration of nutrients, in micrograms per liter, in the epilimnion of the northern end of the lake was multiplied by the annual change in lake volume, in cubic hectometers, to compute the annual nutrient load associated with this budget component. Change in lake volume was computed separately for each year in both studies.

Errors were calculated or estimated for each budget component. Standard errors for the load estimates computed for the St. Joe, Spokane, and Coeur d'Alene Rivers were provided in the LOADEST output as average daily errors for each month. These daily errors were multiplied by the number of days in each month and were then summed for each year 
in the 1991-92 and 2004-06 studies. Errors for nutrient loads from nearshore wastewater and precipitation for the 1991-92 study were reported in Woods and Beckwith (1997); because loads for these budget components were assumed to be constant for the 2004-06 study, errors also were assumed to be constant. Similarly, errors for nutrient loads from ungaged surface-water inflows, ground-water outflows, and lake storage change for the 1991-92 study were reported in Woods and Beckwith (1997). However, these loads were not assumed to be constant for the 2004-06 study. Because loads for these budget components in the 2004-06 study were estimated using relations with loads from the 1991-92 study, errors were assumed to be proportional. An average percent error relative to a load was calculated for the 1991-92 study and applied to the 2004-06 load estimates. For example, the average percent error (error divided by the associated load, in percent) in total nitrogen load in ground-water outflow for the 1991-92 study was 25 percent. Errors in total nitrogen loads in ground-water outflow for each year in the 2004-06 study were calculated by multiplying the annual load by the average percent error in the 1991-92 study (25 percent). Because recent data were unavailable to calculate loads for some budget components, reported errors for the 2004-06 study may not be accurate.

Overall error for each nutrient and trace metal budget was computed using the following equation (Brown, 1987):

$$
\mathrm{OE}=\left(\left(\mathrm{E}_{1}\right)^{2}+\left(\mathrm{E}_{2}\right)^{2}+\ldots+\left(\mathrm{E}_{\mathrm{n}}\right)^{2}\right)^{0.5},
$$

where:

$$
\begin{aligned}
& \text { OE is the overall standard error associated with each } \\
& \text { nutrient or trace metal budget, in kilograms; and } \\
& \mathrm{E}_{\mathrm{n}} \text { is the total standard error associated with each budget } \\
& \text { component, in kilograms. }
\end{aligned}
$$

\section{Depth Profiles and Nutrient Sample Collection}

Status and trends of lake productivity indices such as water-column transparency, nitrogen and phosphorus concentrations, chlorophyll- $a$ concentrations, and dissolvedoxygen concentrations were evaluated using limnological data. Water-column circulation processes also were evaluated on the basis of spatial and temporal changes in nutrients, chlorophyll- $a$, and dissolved-oxygen concentrations.

Prior to collecting water samples at the pelagic stations, full-depth profiles of the water column were measured for temperature, $\mathrm{pH}$, oxidation-reduction potential, specific conductance, dissolved oxygen concentration and percent saturation, light transmissivity (a surrogate for turbidity), and fluorescence (a surrogate for chlorophyll- $a$ ). The upper water column was profiled for PAR to define the euphotic zone depth. Secchi-disc transparency depth was also measured. The euphotic zone is the part of the water column in which PAR is equal to or greater than 1 percent of the PAR incident on the lake surface. Water column samples were collected eight times per year at the five pelagic stations. At the deeper stations $(1,3$, and 4$)$, samples were collected in the euphotic zone (composite), upper hypolimnion, mid-hypolimnion, and lower hypolimnion (1 $\mathrm{m}$ above lakebed). Station 5 was sampled in the euphotic zone and upper and lower hypolimnion, whereas station 6 , the shallowest, was sampled in the euphotic zone and lower hypolimnion. The samples were analyzed for total concentrations of nitrogen and phosphorus and dissolved concentrations of nitrite plus nitrate, ammonia, phosphorus, and orthophosphate. The euphotic zone samples also were analyzed for concentrations of chlorophyll- $a$ and pheophytin. Littoral zone samples were analyzed using the same methods as pelagic euphotic zone samples, except only one 2-m-deep sample was collected at each station.

\section{Trace Metal Sample Collection}

Limnological data were evaluated for the status and trends of trace metal concentrations in the lake. Water column circulation processes also were evaluated on the basis of spatial and temporal changes in trace metal concentrations.

Water column samples for trace metal analyses were collected in conjunction with pelagic zone nutrient samples during both study periods. The samples from the five pelagic stations were analyzed for total and dissolved concentrations of cadmium, lead, zinc, iron, and manganese, as well as hardness. The lower hypolimnion samples also were analyzed for dissolved arsenic. Littoral zone samples were analyzed for the same constituents as the pelagic euphotic zone samples, except only one 2-m-deep sample was collected at each station.

The exchange of constituents between a water column of a lake and lakebed sediments, often termed benthic flux, has been identified as an important water-quality issue for Coeur d'Alene Lake (Horowitz and others, 1993, 1995a, 1995b; Kuwabara and others, 2000; and Woods, 2004). To complement water column sampling and to obtain recent information related to the benthic flux of trace metals, samples near the sediment-water interface were collected at station 4 on each sampling trip during the 2004-06 study. To avoid disturbing the thin veneer of flocculent material at the sediment-water interface, samples were collected by gentle and slow insertion of a modified gravity coring device (with non-metallic core tube liner, core cutter, and core catcher) into the lakebed sediments. Upon retrieval, the water within $0.1 \mathrm{~m}$ of the lakebed (but above the flocculent layer) was gently removed from the core tube liner using a peristaltic pump. The sample was discarded if significant re-suspension of sediment was observed or suspected during retrieval. Analyses for trace metals and nutrients were the same for these samples as the samples from the water column. Analyses also included particulate and dissolved organic carbon (DOC). 


\section{Comparison of Limnological Conditions}

Selected limnological variables common to the 1991-92 and 2004-06 studies were compared to determine changes associated with the interaction of physical, chemical, and biological processes in Coeur d'Alene Lake. The report on the 1991-92 study (Woods and Beckwith, 1997) presents detailed discussions of historical effects on the water quality in Coeur d'Alene Lake and the results of an applied empirical nutrient load/lake response model (Walker, 1987) to evaluate the lake response to nutrient inputs (Woods and Beckwith, 1997).

Where statistical comparisons are made among sampling stations and (or) study periods, various non-parametric statistical techniques were used in the NCSS statistical software package (Hintze, 2006). The techniques used for various data types are:

- Censored data with single or multiple reporting limits-A Kaplan-Meier logrank hypothesis test and a Peto-Prentice score hypothesis test were used to compare analytical values among stations and between study periods. These tests assign percentiles to data points and compare differences in each sampled population's cumulative distribution function. No values are substituted for the censored data. Both methods are identified in Helsel (2005) as appropriate for use in comparing data sets with multiple reporting limits, and both produced identical results in all cases. In addition, a lognormal maximum likelihood estimator regression method (Helsel, 2005) was used to test the significance of changes over time and to support the hypothesis tests.

- Uncensored data (all detected values) - A MannWhitney hypothesis test (Helsel and Hirsch, 2002) was used to compare analytical values among stations and between study periods.

- Paired uncensored data (all detected values) —A Wilcoxon Signed-Ranks hypothesis test (Helsel and Hirsch, 2002) was used to compare paired analytical concentrations:

- Analytical concentrations in samples collected in the euphotic zone and hypolimnion for the same station and collection date,

- Analytical concentrations in samples collected in the lower hypolimnion and sediment-water interface at station 4 for the same collection date, and

- Analytical concentrations in samples collected from pelagic stations and the closest paired littoral stations during the same week.
- Paired censored data-A Wilcoxon Signed-Ranks hypothesis test was used to compare paired analytical values. In the rare case when the paired test was used on censored data, the non-detects were replaced with values equal to their reporting limits. In nearly all cases where this occurred, both paired values were censored and replaced with the same value for the reporting limit.

In nearly all cases, data from calendar years 1991 and 1992 were grouped into one study period referred to as “1991-92”. Likewise, data from water years 2004, 2005, and 2006 were grouped into one study period referred to as "2004-06". The data were grouped and compared as study periods rather than individual years to compare overall differences in lake water quality between the two studies.

In all cases, single- and double-tailed hypothesis tests were employed at a significance level of $\alpha=0.05$. A double-tailed hypothesis test was first used to determine if a significant difference was measured between median values in the sampled populations. If a significant difference was measured, the single-tailed hypothesis test was used to determine which sampled population had a greater median value. Where used in this report, the term "significant" denotes that the comparison was statistically significant at a significance level of $\alpha=0.05$.

\section{Hydrologic, Nutrient, and Trace Metal Budgets}

The fate and transport of water and associated waterquality constituents following their delivery into a lake are determined by the interactions of a myriad of physical, chemical, and biological processes operating in the lake over a wide range of spatial and temporal scales. To evaluate the net effects of those processes in a lake, hydrologic and constituent budgets can be developed by quantifying water and constituent mass entering and exiting the lake. The quantified mass inflow or outflow commonly is referred to as a load, which is defined as the quantity of a constituent passing a riverine cross section per unit of time. Load is calculated as the product of constituent concentration and discharge.

Although the calculation of load is simple mathematically, the method of deriving concentration and discharge can produce substantial differences in load calculations, especially for periods longer than 1 day. Constituent concentration and discharge vary substantially during a year and are nonsynchronous in their temporal variation. Concentrations of dissolved and particulate constituents respond differently to discharge changes. Therefore, constituent loads may vary on a daily, monthly, and (or) annual basis. Various basic to complex methods have been used to process multiple-date data sets of concentration 
and discharge into estimates of seasonal and annual loads. One basic method is to multiply the mean values of concentration and discharge over the period of interest to derive the load. Additional temporal resolution can be gained by linear interpolation of measured values of concentration and discharge to examine daily load variability over the period of interest. More complex methods use linear regression, either simple or multiple, to relate load or concentration to discharge and other explanatory variables such as seasonality and time trend.

Constituent loads typically are quite variable within and among years because discharge changes often are the dominant influence on loads. This is especially true for sediment-associated constituents where the sediment supply is not limited. In this situation, the smallest loads of sedimentassociated constituents measured during a year typically are associated with minimum discharges due to decreased water velocities that produce less erosion and transport. Alternatively, increased water velocities during maximum discharge during a year can result in erosion and transport and large loads of sediment-associated constituents. The pattern generally is similar for dissolved constituents, but differences in loads between high and low discharge are decreased because the transport of dissolved constituents is less dependent on water velocity. These within-year patterns of load variability for sediment-associated and dissolved constituents in a lake are important considerations for determining the effects on the fate and transport of nutrient loads. The transport of seasonal loads also applies to annual loads; large constituent loads generally are transported during high discharge years than during low discharge years.

Table 4 presents streamflow and nutrient loads from the Coeur d'Alene and St. Joe River inflows and the Spokane River outflow from Coeur d'Alene Lake determined using LOADEST, as well as nutrient load estimates from ungaged sources. Robust comparisons among years and load sources are limited by the difference in study periods (calendar year and water year) and the difference in analytical reporting limits between the two studies.

Streamflow for the 5 years varied substantially in response to differences in annual runoff from the watershed and operation of Post Falls Dam. The annual hydrologic conditions for those 5 years in relation to mean hydrologic conditions were compared to the long-term annual streamflow of the USGS gaging station on the Spokane River near Post Falls (USGS gaging station 12419000). The mean annual streamflow at Spokane River near Post Falls during 1912-2006 was 175 m³/s (U.S. Geological Survey, 2007). In comparison, the annual mean streamflows for calendar years 1991 and 1992 and water years 2004, 2005, and 2006 were, $199,99,131,134$, and $186 \mathrm{~m}^{3} / \mathrm{s}$, respectively. Therefore, the percentages of long-term annual mean streamflow among the 5 years were 113, 56, 74, 76, and 106, respectively. Because streamflow is a key factor in the calculation of constituent load, the different hydrologic conditions among the 5 years were responsible for most differences in annual loads delivered into and discharged out of Coeur d'Alene Lake.

The residual for each nutrient load (nitrogen or phosphorus) was computed as the sum of total outflow loads minus the sum of total inflows and is presented in table 4. The residual also is presented as a percentage of the total inflow load. Although the residual can be considered roughly the amount of nutrient load retained in the lake, the estimate contains errors associated with measured and unmeasured budget components. Unquantifiable uncertainties exist in these residual estimates because nutrients in Coeur d'Alene Lake are affected to an unknown degree by physical, chemical, and biological processes.

Total nitrogen inflow and outflow loads decreased between the 1991-92 and 2004-06 study periods. The St. Joe River contributed the largest percentage of inflow total nitrogen load in 1991 (47 percent), and the Coeur d'Alene River contributed slightly higher total nitrogen loads than the St. Joe River in other years studied. Combined, the St. Joe and Coeur d'Alene Rivers contributed an average of 82 percent of the total inflow nitrogen load in the 1991-92 study, but an average of only 40 percent of the total inflow nitrogen load in the 2004-06 study. Estimated inputs from ungaged tributaries and other surface-water inflows constitute a larger percentage of the inflow total nitrogen load in the 2004-06 study (36-46 percent) compared with the 1991-92 study (11-13 percent). Reductions in total nitrogen in the St. Joe and Coeur d'Alene Rivers were expected due to reductions in total nitrogen concentrations and loads in municipal wastewater effluent. For example, effluent monitoring reports from the Coeur d'Alene municipal wastewater treatment plant, which is typical of other wastewater treatment plants on the St. Joe and Coeur d'Alene Rivers, show an increase in total nitrogen removal efficiency from 16 to 56 percent between the 1991-92 and 2004-06 study periods due to improvements in treatment processes. Nutrients in ungaged tributaries and other surfacewater inflows were expected to be from untreated wastewater, agriculture, and natural sources. Nutrient concentrations in these inflows were assumed to be relatively constant between the 1991-92 and 2004-06 studies and, therefore, constituted a larger percentage of the overall inflow total nitrogen load in the latter study. Additional measurements to quantify loads from ungaged tributaries, as well as other ungaged inflows and outflows including nearshore wastewater, precipitation, ground water, and lake storage changes, would improve load estimates and verify assumptions. Load estimates presented in table 4 for ground-water outflow and lake storage change in the 1991-92 study differ slightly from estimates published in Woods and Beckwith (1997) due to a small error in the calculations used to generate those estimates. The Spokane River is the dominant outflow route of total nitrogen from Coeur d'Alene Lake (85-95 percent of total outflow). 
Table 4. Nutrient load budgets and errors, Coeur d'Alene Lake, Idaho, calendar years 1991-92 and water years $2004-06$.

[Sampling locations are shown in figure 1. Sampling locations on the St. Joe and Spokane Rivers changed between the 1991-92 and 2004-06 studies. For comparability, data are normalized to the following stations: St. Joe River: USGS gaging station 12415140, St. Joe River near Chatcolet; Spokane River, USGS gaging station 12417598, Spokane River at Lake Outlet at Coeur d'Alene. Sampling location on the Coeur d'Alene River for both studies was at USGS gaging station 12413860, Coeur d'Alene River near Harrison. Load and error estimates for ungaged tributaries and other surface-water inflow in 1991 and 1992 are from Woods and Beckwith (1997). Loads for ungaged tributaries and other surface-water inflow in 2004-06 were estimated using a relation between 1991-92 load data and annual flow in closest gaged tributary (see text for full explanation). Load and error estimates for nearshore wastewater and precipitation in 1991 and 1992 are from Woods and Beckwith (1997). Assumed nearshore wastewater and precipitation loads and errors were constant for 2004-06 study as no recent data were available. Actual error unknown for loads from ungaged tributaries, surface-water inflow, ground-water outflow, and lake storage change in 2004-06 study. Errors for 2004-06 were estimated by applying the average percent error in loads from the 1991-92 study (see text for full explanation). Loads and errors are in kilograms per year. Streamflows are in cubic hectometers per year. Abbreviations: USGS, U.S. Geological Survey; NA, not applicable]

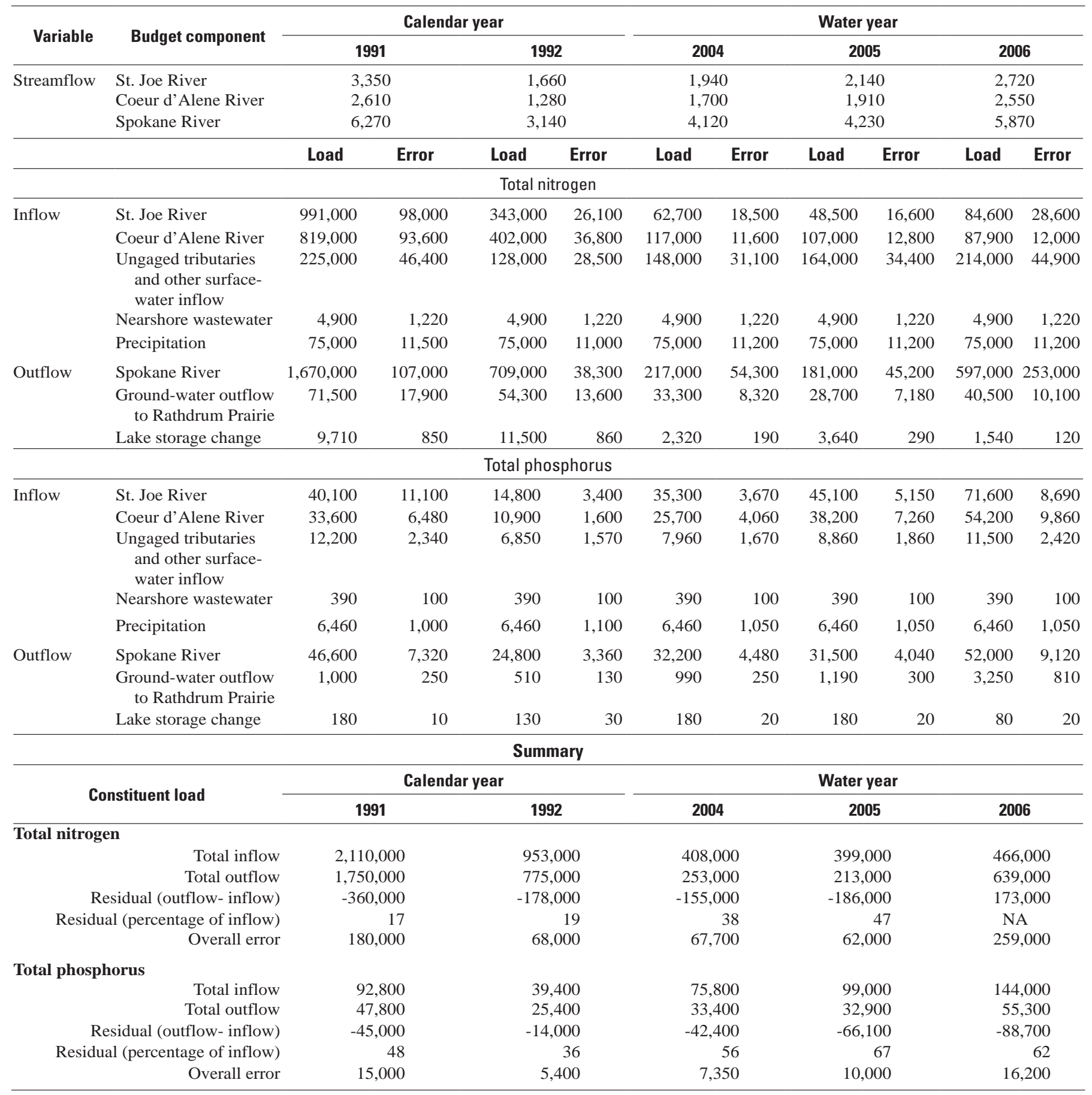


Total nitrogen was retained in the lake in all years studied except water year 2006, when the residual was positive, indicating a higher outflow than inflow of total nitrogen load. However, the residual is less than the overall error in the total nitrogen budget for 2006, and inflow and outflow loads of total nitrogen most likely were equal. Residuals for all other years were larger than the overall corresponding errors and ranged from 17 to 47 percent of the total inflow load.

Total phosphorus inflow and outflow loads fluctuated with streamflow in both study periods, but loads relative to streamflow were higher in the 2004-06 study than the 1991-92 study because total phosphorus concentrations in gaged inflows were statistically higher in the latter study. The St. Joe River contributed the largest percentage of inflow total phosphorus load (38-50 percent) in all years studied. The Coeur d'Alene River was the second largest source, contributing 28-39 percent of the inflow total phosphorus load. Combined, the percent contributions to inflow load from the St. Joe and Coeur d'Alene Rivers were relatively consistent across both study periods (72 percent in the 1991-92 study and 84 percent in the 2004-06 study). Ungaged tributaries and other surface-water inflow comprised the third largest source, contributing 8-13 percent of the inflow total phosphorus load. As with total nitrogen, total phosphorus loads in outflow of the Spokane River (94-98 percent) dominated other outflow routes.

Total phosphorus was retained in the lake in all years studied, and the residuals, expressed as a percentage of inflow, were slightly higher in the 2004-06 study than the 1991-92 study. Residuals for all years were larger than the overall corresponding errors and ranged from 36 to 67 percent of total inflow load.

Table 5 presents selected trace-metal loads from the Coeur d'Alene and St. Joe River inflows and the Spokane River outflow determined using LOADEST. Robust comparisons among years and load sources were hampered by differences in study periods (calendar year and water year), in analytical reporting limits between the two studies, and in sampling locations on the St. Joe and Spokane Rivers, which were not normalized for the trace-metal load budget. Total cadmium loads could not be calculated for the St. Joe River using LOADEST because total cadmium concentrations frequently were less than the method reporting limit.

The largest loads of the three constituents presented (total cadmium, total lead, and total zinc) occurred in 1991, the year of the highest streamflows (table 4). Samples collected in the 2004-06 study at gaging stations on the St. Joe and Spokane Rivers indicated reductions in loads because the trace metal concentrations were within the range of differences in analytical reporting limits used during the two studies. The reporting limit was lowered and more uncensored data points were available for the LOADEST calculations in the 2004-06 study than in the 1991-92 study. Trace metal concentrations for the Coeur d'Alene River exceeded analytical reporting limits used in both studies; therefore, loads at that station were least affected by those differences. The Coeur d'Alene River was, by far, the largest source of trace metal loads to the lake. Combining both study periods, the Coeur d'Alene River contributed an average of 100 percent of total cadmium and 97 percent of total lead and total zinc gaged inflow loads.

An important comparison can be made based on the relative magnitude of constituent loads delivered into the lake as opposed to those discharged out of the lake. The sum of loads from the Coeur d'Alene and St. Joe Rivers was compared to the load at the Spokane River (lake outlet), for total cadmium, total lead, and total zinc (table 5). The retention of the three constituents in the lake, expressed as the residual as a percentage of inflow, was slightly higher in the 2004-06 study period than in the 1991-92 study period. However, not all inflows to the lake could be quantified, and reported residuals may be lower than actual values. The percentage of total cadmium retained ranged from 36 to 70 . A larger percentage of total lead was retained by the lake, ranging from 83 to 96 . These high residuals reflect the propensity of lead to be associated with sediment particles and to be prone to sedimentation in the lake. Zinc is the most soluble of the three trace metals, and the percentage retention in the lake ranged from 33 to 52. Relative to loads, higher errors were present in lead and zinc load estimates for the St. Joe River compared to the Coeur d'Alene and Spokane Rivers.

\section{Water Temperature and Water Column Transparency}

The physical limnological processes of thermal stratification and convective circulation are strongly correlated with the vertical distribution of water-quality properties and constituents. Thermal structure in some lakes may be established, in part, by riverine inflows. However, the major source of heat for most lakes is the short- and long-wave radiation that impinges on the surface of a lake (Wetzel, 1983). Wind energy distributes the surface heat into the water column until density differences impede deeper mixing. In lakes deep enough to resist full-depth convective circulation, solar heating and wind mixing during the summer vertically segregate the water column into three zones: epilimnion, metalimnion, and hypolimnion. The upper zone, the epilimnion, is the stratum in which most biological production occurs because light generally is sufficient to drive photosynthetic production by phytoplankton. The metalimnion is the stratum of maximum temperature change; density differences may be sufficient to impede settling of detrital material into the lower stratum, the hypolimnion. A thermocline is present within the metalimnion if the rate of temperature change exceeds $1^{\circ} \mathrm{C} / \mathrm{m}$. The hypolimnion, which overlies the lakebed sediments, typically is more thermally stable than the epilimnion or metalimnion. During thermal 
Table 5. Selected trace-metal loads and errors measured at three gaging stations near Coeur d'Alene Lake, Idaho, calendar years 1991-92 and water years 2004-06.

[Sampling locations are shown in figure 1. Sampling locations on the St. Joe and Spokane Rivers changed between the 1991-92 and 2004-06 studies. Few differences in trace-metal inputs are expected between sampling locations. Locations sampled in 1991-92 study: St. Joe River, USGS gaging station 12415075, St. Joe River at St. Maries; Spokane River, USGS gaging station 12419000, Spokane River near Post Falls. Locations sampled in 2004-06 study: St. Joe, USGS gaging station 12415140, St. Joe River near Chatcolet; Spokane River, USGS gaging station 12417598, Spokane River at Lake Outlet at Coeur d’Alene. Sampling location on the Coeur d'Alene River for both studies was at USGS gaging station 12413860, Coeur d'Alene River near Harrison. Loads and errors are in kilograms per year. Streamflows are in cubic hectometers per year. Abbreviations: ND, analyte concentration frequently less than method reporting limit; unable to calculate loads using LOADEST; USGS, U.S. Geological Survey ; NA, not applicable]

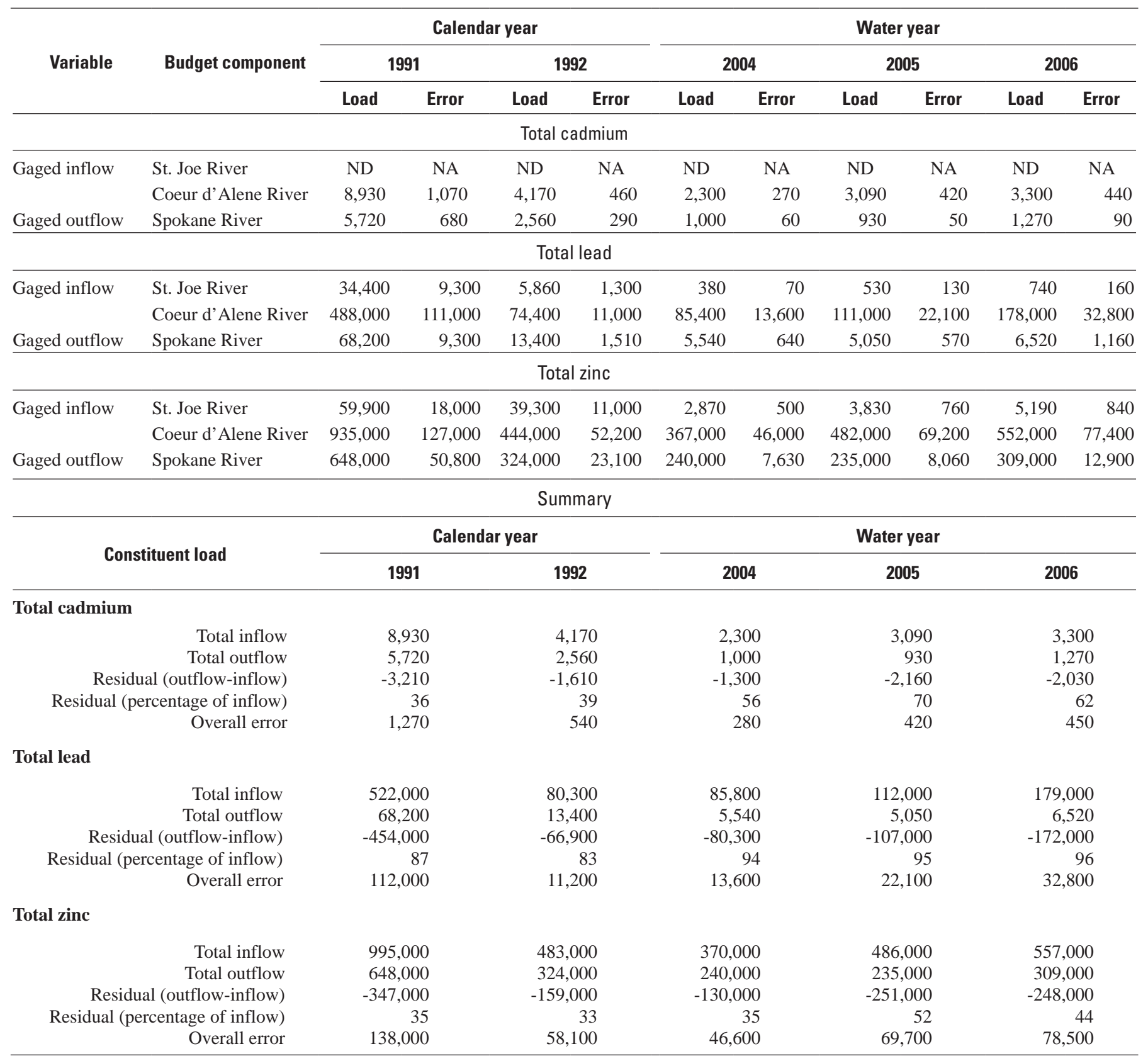


stratification, the hypolimnion is isolated from atmospheric exchange and may develop a dissolved oxygen deficit if biological and chemical oxygen demands exceed the oxygen mass available within the hypolimnion at the onset of thermal stratification. During spring and autumn, solar radiation input is less than during summer, and windy conditions often are more prevalent. This combination facilitates convective circulation, the process whereby a weakly stratified water column undergoes vertical mixing when wind energy is sufficient to overcome the thermal gradient. A lake is termed dimictic if it undergoes convective circulation throughout its water column in spring and autumn. Such mixing is an important mechanism for the vertical movement of waterquality constituents such as dissolved oxygen, nutrients, and trace metals.

Heating of Coeur d'Alene Lake during the 1991-92 and 2004-06 studies produced annual maximum water temperatures within $1.2^{\circ} \mathrm{C}$ among the 5 years compared. The maximum water temperature measured during 1991 was $23.4^{\circ} \mathrm{C}$ at station 6 during early August and, during 1992, $23.2^{\circ} \mathrm{C}$ at station 6 during late June (Woods and Beckwith, 1997; appendix A). Maximum water temperatures for 2004, 2005, and 2006 were $22.6^{\circ} \mathrm{C}$ (station 6, mid-July), $22.2^{\circ} \mathrm{C}$ (station 6, mid-July), and $22.4^{\circ} \mathrm{C}$ (station 4, mid-August), respectively (appendix B).

These similarities in maximum water temperatures did not result in similar thermocline depths among the stations for the 5 years. The median thermocline depths for stations 1,3 , 4,5 , and 6 during the two study periods ranged from $5.5 \mathrm{~m}$ at station 6 in 2004-06 to $13 \mathrm{~m}$ at station 1 in 1991-92 (fig. 3). At each station, median thermocline depths varied by as little as $1.5 \mathrm{~m}$ (station 6) and by as much as $3.5 \mathrm{~m}$ (station 5). These differences reflect numerous influences on a location's propensity to stratify thermally; important influences include depth, exposure to wind, proximity to riverine inflows, and exposure to internal waves at the thermocline (Woods, 2004).

The development and breakdown of thermal stratification have important consequences for the fate and transport of constituents in lakes. At the deep stations in Coeur d'Alene Lake (stations 1, 3, and 4), thermal stratification (depicted by the presence of a thermocline) developed by mid-July and persisted until early October 1991. In 1992, the thermocline developed by June and persisted until mid-October (Woods and Beckwith, 1997, fig. 9). During 2004, thermoclines developed by mid-June and persisted into mid-October, except at station 4 where the thermocline disappeared prior to the October sampling trip (appendix B). The thermoclines at stations 3 and 4 developed in mid-June 2005, following an earlier development in late May at station 1; thermoclines at these three stations disappeared by early October (appendix B). During 2006, thermoclines developed by
mid-June and persisted into mid- October, except at station 4 which was not sampled during the October sampling trip (appendix B). The thermocline at station 4 was detected in late August.

Water column transparency was characterized as Secchidisc transparency depth and euphotic zone depth, both of which are shown in figure 3 as median values for each station for the two study periods. The smallest medians for both variables were measured at station 6 , the shallowest of the five stations and the most exposed to turbid riverine inflows from the St. Joe River. The three deep stations had similar median values although the largest values for Secchi-disc transparency depth were recorded at station 1 , the farthest from riverine inflows. The variation of euphotic zone depth among the five stations was similar to that of Secchi-disc transparency depth. Some lack of correspondence between the two variables at a station likely is due to the subjective nature of measuring Secchi-disc transparency depth.

The foregoing comparison of water temperatures and water column transparency among the study periods and the five stations indicated no substantive changes in water column heating and convective circulation because heating and circulation are largely driven by physical limnological processes, which have not changed at Coeur d'Alene Lake. Anthropogenically induced changes in sediment delivery to the lake and (or) increased phytoplankton productivity have the potential to affect water column transparency. No such effects were detected with these data. A longitudinal gradient exists from south (low transparency) to north (high transparency) as a consequence of turbid riverine inflows entering the lake from the south.

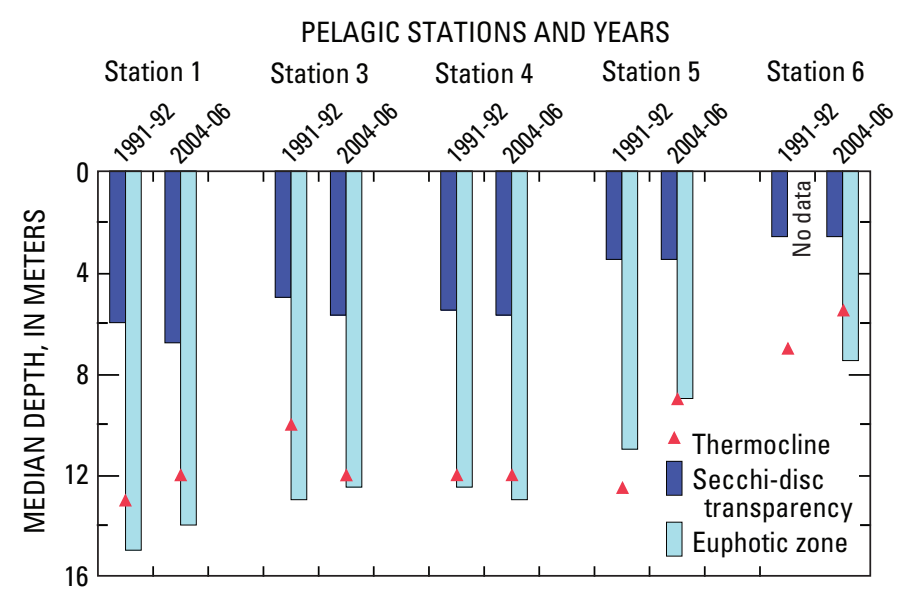

Figure 3. Median depths of thermocline, Secchi-disc transparency, and euphotic zone at five pelagic stations, Coeur d'Alene Lake, Idaho, calendar years 1991-92 and water years 2004-06. 


\section{Dissolved Oxygen Concentration and Percent Saturation}

The concentration of dissolved oxygen in water is affected by temperature, barometric pressure, oxygen production by photosynthesis, oxygen consumption by respiration and decomposition, exchange across the airwater interface, and mixing (Hem, 1985). The temporal and spatial distributions of dissolved-oxygen concentrations in lakes are important indices of water quality. However, some effects described earlier in this report concealed important processes that can be better evaluated with the variable percent saturation of dissolved-oxygen concentration, defined here as the ratio (expressed as a percentage) of measured dissolvedoxygen concentration to that which would exist under saturated conditions at the same temperature.

During the 1991-92 study, the overall range in dissolvedoxygen concentrations over depth and time among the pelagic stations was 0 to $13.6 \mathrm{mg} / \mathrm{L}$; both extremes were measured at station 6 (Woods and Beckwith, 1997; appendix A). The overall range in dissolved oxygen concentrations during 2004-06 was 0.2 to $13.7 \mathrm{mg} / \mathrm{L}$ with the minimum measured at station 6 and the maximum at station 1 (appendix B). Over the two study periods, the highest concentrations at each station were measured in the winter in association with minimum water temperatures confirming the inverse relation between dissolved-oxygen concentration and temperature. Minimum concentrations were measured in the hypolimnia of each station during late summer or autumn as prolonged thermal stratification restricted mixing of the oxygenated upper water column with the hypolimnion.

Ranges for the percent saturation of dissolved-oxygen concentrations for the 5 stations during the study periods are plotted in figure 4. Wider ranges and smaller minimum values were recorded at stations 5 and 6. Station 6 attained anoxic or near-anoxic conditions in each year; station 5 percent saturations were as low as 24 in the 2004-06 study. Similar minimum percent saturations, ranging from 54 to 65 , were recorded at the three deep stations (1, 3, and 4), which have not shown hypolimnetic anoxia.

Saturations greater than 100 percent were measured at all stations in 4 or more of the 5 years. These saturations were associated with the euphotic zone during the summer months when photosynthetic-oxygen production exceeded oxygen consumption processes. The minimum percent saturations were in the hypolimnia of the stations during late summer or autumn.

A statistical analysis of dissolved-oxygen concentrations and percent saturations among the two study periods and five stations (tested separately) indicated no significant change between study periods. At all stations, median dissolvedoxygen concentrations were significantly lower in the hypolimnion than in the euphotic zone. Median concentrations were significantly lower at stations 5 and 6 than at all other stations for both study periods. A significant longitudinal gradient in the loss of dissolved oxygen is apparent from north to south. However, that gradient is mostly a consequence of the shallow depths and higher biological productivity at stations 5 and 6.

\section{Total Phosphorus}

Phosphorus is one of several essential nutrients in the metabolism of phytoplankton and aquatic plants and was measured in both studies. Eutrophication research has focused heavily on phosphorus, the nutrient often having the smallest supply-to-demand ratio for aquatic plant growth (Ryding and Rast, 1989). Phosphorus concentrations for both studies were reported as total phosphorus and dissolved orthophosphate (dissolved phosphorus also was reported for the 2004-06 study). Total phosphorus represents phosphorus in solution (dissolved or colloidal) and phosphorus contained in or attached to biotic and abiotic particulate material. Dissolved phosphorus and orthophosphate are determined from the filtrate that passes through a filter with a nominal pore size of $0.45 \mu \mathrm{m}$.

The comparison of phosphorus focused on total phosphorus because analytical method reporting limits for dissolved orthophosphate differed between the two studies, resulting in numerous non-detected orthophosphate values in the 2004-06 study. Table 6 presents changes in method reporting limits and number of non-detected values in the 1991-92 and 2004-06 studies for relevant constituents, including dissolved orthophosphate. During the 1991-92

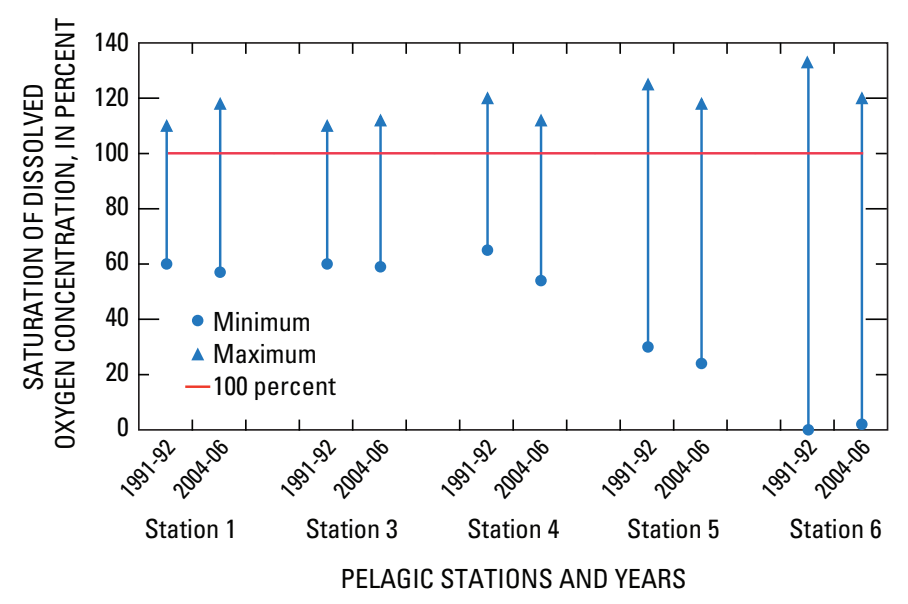

Figure 4. Minimum and maximum percent saturation of dissolved oxygen at five pelagic stations, Coeur d'Alene Lake, Idaho, calendar years 1991-92 and water years 2004-06. 
study, the method reporting limit for dissolved orthophosphate was $1 \mu \mathrm{g} / \mathrm{L}$; mean concentrations over the 2 years were slightly more than $1 \mu \mathrm{g} / \mathrm{L}$ (Woods and Beckwith, 1997), but median concentrations at all pelagic stations except station 6 were less than $1 \mu \mathrm{g} / \mathrm{L}$. The more rigorous statistical basis for method reporting limits (Childress and others, 1999) applied during the 2004-06 study resulted in a reporting limit of $6 \mu \mathrm{g} / \mathrm{L}$. About 78 percent of dissolved orthophosphate analyses in the 2004-06 study were non-detected values, and lake-wide median orthophosphate concentrations at all pelagic stations in the 2004-06 study were non-detected values, less than $6 \mu \mathrm{g} / \mathrm{L}$. Therefore, statistical comparisons were made only for total phosphorus. The comparisons were made using the Kaplan-Meier logrank and Peto-Prentice score tests, incorporating the multiple reporting limits for total phosphorus.

Total phosphorus concentrations among the pelagic stations ranged from less than 1 to $192 \mu \mathrm{g} / \mathrm{L}$ during 1991-92 (Woods and Beckwith, 1997; appendix A). The largest concentration measured was under anoxic conditions within the hypolimnion of station 6 during September 1991. Total phosphorus concentrations for 2004-06 ranged from 2 (estimated) to $168 \mu \mathrm{g} / \mathrm{L}$ with the largest concentration from the anoxic hypolimnion of station 6 during August 2006 (appendix B). Median concentrations of total phosphorus within the euphotic zone and hypolimnion of each station for both study periods are shown in figure 5 . A significant longitudinal gradient is evident from south to north, with higher concentrations associated with the two shallower, southern stations. When grouped by study, total phosphorus concentrations were significantly higher in the euphotic zone and hypolimnion in the 2004-06 study than in the 1991-92 study at all pelagic stations, which corresponds with the increase in total phosphorus loads and concentrations in inflows from the Coeur d'Alene and St. Joe Rivers.

The differences in median concentrations of total phosphorus between euphotic zone and hypolimnion at each station (fig. 5) reveal that water quality differed at the three deeper stations than the two shallower stations. During each study period, statistically similar concentrations for the two depth zones were detected at the deeper stations (1, 3, and 4). In most cases the difference was only $1 \mu \mathrm{g} / \mathrm{L}$ or less. In contrast, the concentration differences between the euphotic zone and hypolimnion of stations 5 and 6 ranged from 2.5 to $3 \mu \mathrm{g} / \mathrm{L}$ and from 5.5 to $7 \mu \mathrm{g} / \mathrm{L}$, respectively. The hypolimnetic phosphorus concentrations at stations 5 and 6 significantly exceeded those of their euphotic zones in all cases.

Higher median concentrations of total phosphorus within the euphotic zones and hypolimnia of stations 5 and 6 , compared to the concentrations detected at the deeper pelagic stations, reflect several processes. Seasonal anoxia at station 6 releases dissolved constituents such as phosphorus, nitrogen, iron, and manganese from lakebed sediments and detrital material within the water column. Additionally, both stations are within the inflow plume of the St. Joe River, which is a primary source of phosphorus for the lake.

Total phosphorus was not detected in any of the blank samples submitted during the 2004-06 study; therefore, decontamination procedures were considered adequate to remove this constituent from sampling equipment. Mean

Table 6. Changes in method reporting limits for selected constituents sampled in Coeur d'Alene Lake, Idaho, calendar years 1991-92 and water years 2004-06.

[Abbreviations: $\mu \mathrm{g} / \mathrm{L}$, microgram per liter; MRL, method reporting limit]

\begin{tabular}{|c|c|c|c|c|c|c|c|c|}
\hline \multirow[b]{3}{*}{ Constituent } & \multicolumn{8}{|c|}{ Study } \\
\hline & \multicolumn{4}{|c|}{ 1991-92 } & \multicolumn{4}{|c|}{ 2004-06 } \\
\hline & $\begin{array}{c}\text { MRL } \\
(\mu \mathrm{g} / \mathrm{L})\end{array}$ & $\begin{array}{c}\text { Number of } \\
\text { analyses }\end{array}$ & $\begin{array}{c}\text { Number } \\
\text { of non- } \\
\text { detected } \\
\text { values }\end{array}$ & $\begin{array}{c}\text { Percent } \\
\text { non- } \\
\text { detected } \\
\text { values }\end{array}$ & $\begin{array}{c}\text { MRL } \\
(\mu \mathrm{g} / \mathrm{L})\end{array}$ & $\begin{array}{c}\text { Number of } \\
\text { analyses }\end{array}$ & $\begin{array}{l}\text { Number } \\
\text { of non- } \\
\text { detected } \\
\text { values }\end{array}$ & $\begin{array}{c}\text { Percent } \\
\text { non- } \\
\text { detected } \\
\text { values }\end{array}$ \\
\hline Total ammonia plus organic nitrogen & 200 & 312 & 244 & 78 & 60 & 403 & 1 & .25 \\
\hline Dissolved inorganic nitrogen & 7.0 & 327 & 9 & 2.8 & 26 & 404 & 63 & 16 \\
\hline Dissolved nitrite plus nitrate & 5.0 & 327 & 61 & 19 & 16 & 404 & 90 & 22 \\
\hline Dissolved ammonia & 2.0 & 327 & 32 & 10 & 10 & 404 & 189 & 47 \\
\hline Total cadmium & 1.0 & 126 & 117 & 93 & .040 & 404 & 44 & 11 \\
\hline
\end{tabular}




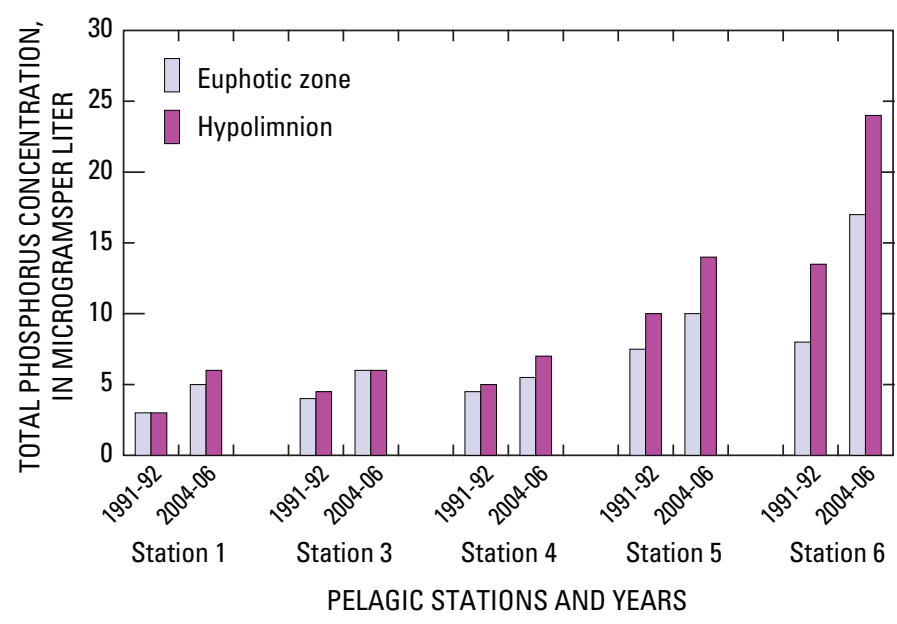

Figure 5. Median concentrations of total phosphorus in the euphotic zone and hypolimnion at five pelagic stations, Coeur d'Alene Lake, Idaho, calendar years 1991-92 and water years 2004-06.

relative standard deviation, a measure of variability induced during sample processing and analysis, was 12 percent for total phosphorus, based on replicate sample data collected during the 2004-06 study. Most of the high relative standard deviations were for samples with total phosphorus concentrations less than $10 \mu \mathrm{g} / \mathrm{L}$. At these concentrations, small differences between concentrations in replicate and routine samples can inflate the relative standard deviation. Total phosphorus concentrations in 38 percent of the replicate samples matched exactly with corresponding routine samples. Selected analytical data for quality control samples collected during the 2004-06 study are provided in appendix C.

\section{Dissolved Inorganic Nitrogen}

Nitrogen, like phosphorus, is essential to the metabolism of aquatic biota. In Coeur d'Alene Lake, the supply-to-demand ratio of nitrogen is small (but typically not as small as that of phosphorus); thus nitrogen may limit the growth of aquatic plants. The nitrogen cycle in aquatic ecosystems is complex because nitrogen can assume many redox states and chemical forms, and because most processes involving nitrogen are biologically mediated. In aquatic ecosystems, nitrogen commonly exists as dissolved molecular nitrogen, nitrogencontaining organic compounds, ammonia, nitrite, and nitrate. Nitrogen concentrations for the two studies generally were reported as total nitrogen and dissolved inorganic nitrogen. Total nitrogen represents the sum of ammonia, organic nitrogen, nitrite, and nitrate in solution (dissolved or colloidal) and contained in or attached to biotic and abiotic particulate material. Dissolved inorganic nitrogen represents the sum of ammonia, nitrite, and nitrate and is determined from the filtrate that passes through a filter with a nominal pore size of $0.45 \mu \mathrm{m}$.

Comparisons involving nitrogen focused on dissolvedinorganic nitrogen concentrations because analytical method reporting limits for total-nitrogen concentrations differed greatly between the two studies. The method reporting limit for total nitrogen during 1991-92 was $205 \mu \mathrm{g} / \mathrm{L}$ (200 $\mu \mathrm{g} / \mathrm{L}$ for total ammonia plus organic nitrogen and $5 \mu \mathrm{g} / \mathrm{L}$ for dissolved nitrite plus nitrate [table 6]); as such, nearly all total nitrogen concentrations in Coeur d'Alene Lake were reported as less than $205 \mu \mathrm{g} / \mathrm{L}$ for that period. Improved analytical methods prior to the 2004-06 study lowered the reporting limit to $60 \mu \mathrm{g} / \mathrm{L}$. This change effectively negated the ability to make comparisons of total nitrogen between the two studies.

Method reporting limits for dissolved nitrite plus nitrate and dissolved ammonia also differed between the two studies as shown in table 6; however, the incidence of concentrations less than the reporting limit was much less than for total nitrogen. During the 1991-92 study, method reporting limits were 5 and $2 \mu \mathrm{g} / \mathrm{L}$ as nitrogen for dissolved nitrite plus nitrate and dissolved ammonia, respectively. During the 2004-06 study, a more rigorous statistical basis for method reporting limits (Childress and others, 1999) resulted in reporting limits of 16 and $10 \mu \mathrm{g} / \mathrm{L}$ as nitrogen, respectively, for dissolved nitrite plus nitrate and dissolved ammonia.

Dissolved inorganic nitrogen concentrations among the pelagic stations ranged from less than 7 to $332 \mu \mathrm{g} / \mathrm{L}$ (320 $\mu \mathrm{g} / \mathrm{L}$ of which was ammonia) during 1991-92 (Woods and Beckwith, 1997). The largest concentration was measured under anoxic conditions within the hypolimnion of station 6 during September 1991. The dissolved inorganic nitrogen concentrations for 2004-06 ranged from less than 21 to about $265 \mu \mathrm{g} / \mathrm{L}$ ( $249 \mu \mathrm{g} / \mathrm{L}$ of which was ammonia), with the largest concentration from the anoxic hypolimnion of station 6 during late August 2004.

Median concentrations of dissolved inorganic nitrogen within the euphotic zone and hypolimnion of each station are shown in figure 6. Due to an increase in method reporting limits for the 2004-06 study, median concentrations in the euphotic zone for 2004-06 were less than $26 \mu \mathrm{g} / \mathrm{L}$ at all five stations. Unlike median total phosphorus concentrations in the euphotic zone (fig. 5), no distinct longitudinal gradient for median concentrations of dissolved inorganic nitrogen was evident over the five stations in the euphotic zone (fig. 6). However, such a gradient did exist for hypolimnetic concentrations (fig. 6). The three deep stations had significantly higher median concentrations of dissolved inorganic nitrogen than did stations 5 and 6, with station 4 having the highest median concentrations. Median hypolimnetic concentrations for the three deep stations ranged 


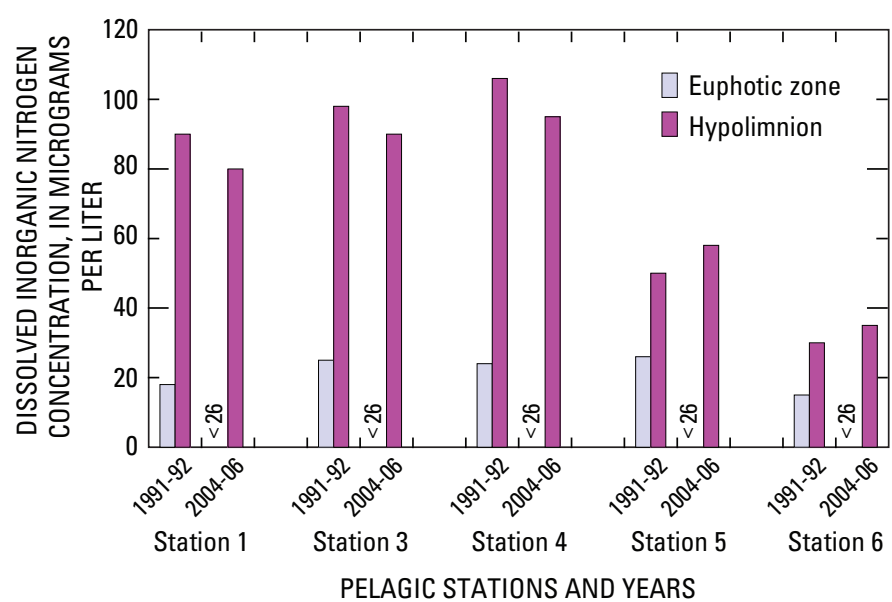

Figure 6. Median concentrations of dissolved inorganic nitrogen in the euphotic zone and hypolimnion at five pelagic stations, Coeur d'Alene Lake, Idaho, calendar years 1991-92 and water years 2004-06.

from $80 \mu \mathrm{g} / \mathrm{L}$ (station 1 in 2004-06) to $106 \mu \mathrm{g} / \mathrm{L}$ (station 4 in 1991-92). In contrast, the range for median hypolimnetic concentrations at stations 5 and 6 was from $30 \mu \mathrm{g} / \mathrm{L}$ (station 6 in 1991-92) to $58 \mu \mathrm{g} / \mathrm{L}$ (station 5 in 2004-06).

The significant differences in median concentrations of dissolved inorganic nitrogen between the euphotic zone and hypolimnion of the three deep stations (ig. 6) were attributable to several limnological processes. The greater depth of stations 1,3 , and 4 decreased the frequency of convective circulation and allowed development of waterquality stratification during summer. Phytoplanktonic assimilation of dissolved inorganic nitrogen decreased summertime concentrations within the euphotic zone (Woods, 2004); this process also occurred at stations 5 and 6. Additionally, the highest loads and concentrations of dissolved inorganic nitrogen were delivered to the lake during winter months, when inflow plumes travel through the lake as underflow. As lower-concentration inflows in other seasons flushed through the lake as overflow or interflow, some higher concentration contributions may have been trapped throughout the year in the deeper areas of the lake. The process of benthic flux likely served to enrich hypolimnetic concentrations at the deeper stations as well as station 5 .

No significant temporal changes were detected in hypolimnetic dissolved inorganic nitrogen between study periods at any pelagic station. A statistical comparison in dissolved inorganic nitrogen in the euphotic zone between study periods was hampered by the change in reporting limits and number of reported non-detected values in the 2004-06 study. In the 1991-92 and 2004-06 studies, a significant difference existed between euphotic zone and hypolimnetic concentrations at all five stations, but particularly at the three deep stations. As previously discussed, a robust comparison was difficult for all nitrogen fractions between the two studies because of differences in method reporting limits.

Dissolved ammonia, nitrite, and nitrate were not detected in any of the blank samples submitted during the 2004-06 study; therefore, decontamination procedures were deemed adequate to remove these analytes from sampling equipment. Mean relative standard deviations were 8 percent for dissolved ammonia and 1 percent for dissolved nitrite plus nitrate, based on replicate sample data collected during the 2004-06 study. As with total phosphorus, most high relative standard deviations were for samples with low concentrations. Seventyone percent of ammonia analyses and 50 percent of nitrite plus nitrate analyses in replicate samples matched corresponding routine samples.

\section{Limiting Nutrient}

The limiting nutrient concept states that the ultimate yield of a crop will be limited by the essential nutrient most scarce relative to the specific needs of the crop (Ryding and Rast, 1989). This concept, in concert with the stoichiometry of the photosynthesis equation, has led to the widespread use of nitrogen-to-phosphorus ratios (N:P). These ratios commonly are used in eutrophication studies to evaluate if nitrogen or phosphorus was the nutrient most likely to limit phytoplankton growth. The atomic ratio of nitrogen to phosphorus, $16 \mathrm{~N}: 1 \mathrm{P}$, in the photosynthesis equation corresponds to a mass ratio of 7.2N:1P. Typically, N:P values are calculated using the biologically available form of these two nutrients, dissolved inorganic nitrogen and dissolved orthophosphate. If $\mathrm{N}: \mathrm{P}$ (by weight) is less than 7.2, then nitrogen may be limiting, whereas if $\mathrm{N}$ :P exceeds 7.2, then phosphorus may be limiting (Ryding and Rast, 1989).

The mean euphotic zone values of N:P for Coeur d'Alene Lake previously published for the 1991-92 study (Woods and Beckwith, 1997) were 34.4 for 1991 and 22.7 for 1992 and indicated a strong tendency towards phosphorus limitation of phytoplankton growth. The lower value for 1992 was a consequence of lower concentrations of dissolved inorganic nitrogen because dissolved orthophosphate concentrations were comparable during both years.

The calculation of N:P for 2004-06 dissolved inorganic nitrogen data was complicated by a reporting limit of $6 \mu \mathrm{g} / \mathrm{L}$ for dissolved orthophosphate and median concentrations of dissolved inorganic nitrogen less than $26 \mu \mathrm{g} / \mathrm{L}$ for 2 years in the study. These complications resulted in few samples with dissolved orthophosphate and dissolved inorganic nitrogen greater than their respective reporting limits. Values of both constituents for the calculation of N:P ratios were detected in only 36 percent of samples collected during the 1991-92 study and 19 percent of samples collected during the 2004-06 study. However, for a general comparison between study periods, the median $\mathrm{N}: \mathrm{P}$ ratio values for each station when 
dissolved orthophosphorus and dissolved inorganic nitrogen were detected were calculated and compared. Median detected $\mathrm{N}: \mathrm{P}$ ratios in the 1991-92 study ranged from 16 (station 6) to 26 (station 5). Median detected N:P ratios in the 2004-06 study ranged from 7 (station 6) to 13 (station 3). Whereas the lake was clearly phosphorus-limited during 1991-92, the lake may have been much closer to the boundary value of 7.2 that separates nitrogen from phosphorus limitation during 2004-06. However, the data are insufficient to draw reliable conclusions regarding limiting nutrients.

\section{Chlorophyll-a}

Chlorophyll- $a$ is the primary photosynthetic pigment of phytoplankton and, as such, is used as an estimator of phytoplankton biomass and an indicator of lake productivity. As discussed previously, the comparison of chlorophyll- $a$ concentrations between the two studies must recognize that different analytical methods were used. Concentrations of chlorophyll- $a$ from samples collected in 1991-92 were adjusted using the NWQL regression equation to estimate the results that would have been expected using the fluorometric method that was applied in 2004-06. Adjusted concentrations from 1991-92 were used in statistical comparisons among stations and study periods.

Adjusted chlorophyll- $a$ concentrations in Coeur d'Alene Lake during 1991-92 ranged from less than 0.1 to $3.1 \mu \mathrm{g} / \mathrm{L}$; the highest concentrations were measured at stations 5 and 6 in both years (Woods and Beckwith, 1997; appendix A). Chlorophyll- $a$ concentrations during 2004-06 (analyzed fluorometrically) ranged from less than 0.1 to $17.9 \mu \mathrm{g} / \mathrm{L}$; the highest concentrations were measured at station 6 (appendix B). However, differences in median concentrations among stations were not statistically significant, and therefore, no spatial pattern was detected.

Median concentrations of chlorophyll- $a$ within the euphotic zone of the five stations are plotted for each year in figure 7. Median concentrations increased significantly at all stations in the 2004-06 study compared to the 1991-92 study. Adjusted median concentrations for 1991-92 ranged from $0.9 \mu \mathrm{g} / \mathrm{L}$ (stations 1, 3, and 4) to $1.2 \mu \mathrm{g} / \mathrm{L}$ (station 6). For 2004-06, median concentrations ranged from $1.5 \mu \mathrm{g} / \mathrm{L}$ (station 5) to $2.7 \mu \mathrm{g} / \mathrm{L}$ (station 6). For comparison, the unadjusted median values for the 1991-92 study also are plotted on figure 7. Although adjusted chlorophyll- $a$ concentrations for the 1991-92 study increased compared to the unadjusted concentrations, they were still significantly less than concentrations during 2004-06 at every station.

Blank samples were not analyzed for chlorophyll- $a$ during the 2004-06 study. One replicate sample was analyzed for chlorophyll- $a$; relative standard deviation was 5 percent in comparison with the corresponding routine sample.

\section{Trophic State}

A nutrient load study conducted in 1975 as part of the National Eutrophication Survey led to the determination that Coeur d'Alene Lake was mesotrophic, or moderately productive (U.S. Environmental Protection Agency, 1977), which prompted continued observation of the lake trophic status. The 1991-92 study determined that the lake had become oligotrophic, or less productive, in terms of lake-wide mean chlorophyll- $a$ and total phosphorus concentrations and mesotrophic in terms of Secchi-disc transparency depth, likely due to the documented reduction in nutrient loads throughout the basin from 1975 to 1991 (Woods and Beckwith, 1997). Although lake-wide mean chlorophyll- $a$ and total phosphorus concentrations during the 2004-06 study have increased, the trophic status classification remained the same as determined by the 1991-92 study based on these variables. Lake-wide median values for the three limnological variables used to classify the trophic status are presented for both studies and compared to trophic classification data from Wetzel (1983) in table 7. Wetzel (1983) classifies a lake as oligotrophic if average or median total phosphorus concentrations are in the range of 3.0-17.7 $\mu \mathrm{g} / \mathrm{L}$, average or median chlorophyll- $a$ concentrations are in the range of $0.3-4.5 \mu \mathrm{g} / \mathrm{L}$, and average or median Secchi-disc transparency depths are in the range of 5.4-28.3 m. Because the lake-wide median Secchi-disc transparency depth for Coeur d'Alene Lake (4.6 m) was less than this range, the lake is classified as mesotrophic based on this variable. The mesotrophic classification range for median Secchi-disc transparency depth is 1.5-8.1 m. Wetzel (1983) provides detailed discussion of the boundaries that separate trophic classifications.

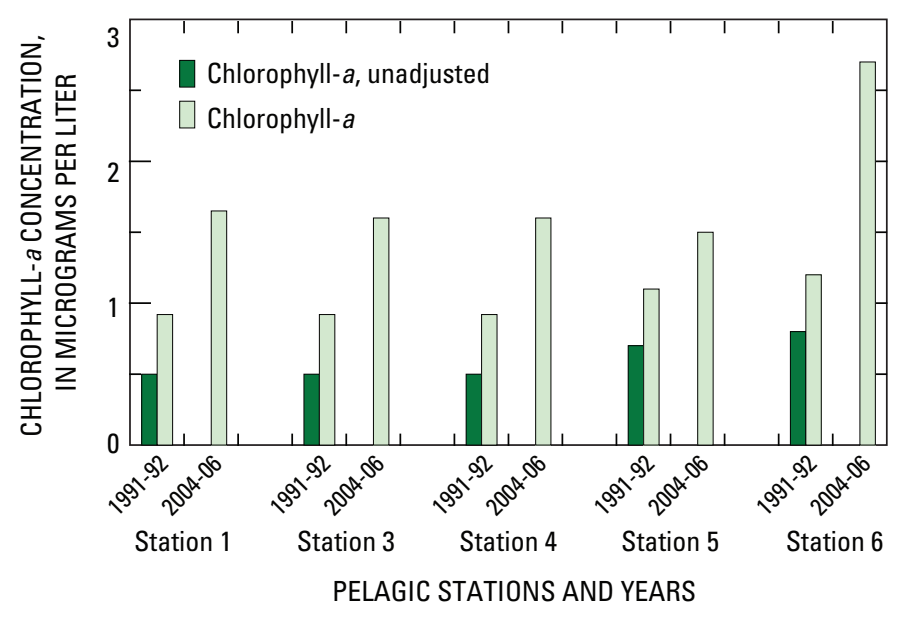

Figure 7. Median concentrations of chlorophyll- $a$ in the euphotic zone at five pelagic stations, Coeur d'Alene Lake, Idaho, calendar years 1991-92 and water years 2004-06. 
Table 7. Trophic state based on lake-wide median values for three limnological variables, Coeur d'Alene, Idaho, calendar years 1991-92 and water years 2004-06.

[TS classification source: Wetzel, 1983. Abbreviations: $\mu \mathrm{g} / \mathrm{L}$, microgram per liter; m, meter; TS, trophic state; O, oligotrophic; M, mesotrophic]

\begin{tabular}{|c|c|c|c|c|c|c|c|c|c|}
\hline \multirow[b]{2}{*}{ Study } & \multicolumn{3}{|c|}{ Total phosphorus ( $\mu \mathrm{g} / \mathrm{L})$} & \multicolumn{3}{|c|}{ Chlorophyll-a ( $\mu \mathrm{g} / \mathrm{L})$} & \multicolumn{3}{|c|}{ Secchi-disc transparency depth (m) } \\
\hline & Median & TS & $\begin{array}{c}\text { TS } \\
\text { classification } \\
\text { range for } \\
\text { median }\end{array}$ & Median & TS & $\begin{array}{c}\text { TS } \\
\text { classification } \\
\text { range for } \\
\text { median }\end{array}$ & Median & TS & $\begin{array}{c}\text { TS } \\
\text { classification } \\
\text { range for } \\
\text { median }\end{array}$ \\
\hline 1991-92 & 5.0 & $\mathrm{O}$ & $3.0-17.7$ & 0.5 & $\mathrm{O}$ & $0.3-4.5$ & 4.4 & M & $1.5-8.1$ \\
\hline 2004-06 & 7.0 & $\mathrm{O}$ & $3.0-17.7$ & 1.7 & $\mathrm{O}$ & $0.3-4.5$ & 4.6 & M & $1.5-8.1$ \\
\hline
\end{tabular}

\section{Trace Metals}

The comparison of trace metal concentrations between the two studies was restricted to total concentrations because dissolved concentrations were not analyzed in the 1991-92 study. Of the 126 samples collected from the euphotic zone and hypolimnion during the 1991-92 study, median totalrecoverable concentrations were less than $1,3.3$, and 98.6 $\mu \mathrm{g} / \mathrm{L}$, respectively, for cadmium, lead, and zinc (Woods and Beckwith, 1997). About 93 percent of cadmium, 24 percent of lead, and 13 percent of zinc concentrations were less than their analytical reporting limits of 1,1 , and $10 \mu \mathrm{g} / \mathrm{L}$, respectively (table 6). Most trace-metal concentrations from station 6 were reported as "less-than" or censored data.

Zinc concentrations were the focus of a comparison of median concentrations in euphotic zone and hypolimnion samples from the five stations during the two studies (fig. 8). Concentrations in 2004-06 significantly decreased from those measured during 1991-92 for the euphotic zone and hypolimnion and at all stations except station 6 . At every pelagic station except station 6, paired zinc concentrations were significantly higher in the hypolimnion than in the euphotic zone. During 1991-92, median zinc concentrations ranged from less than 10 (station 6) to $100 \mu \mathrm{g} / \mathrm{L}$ (station 4) in the euphotic zone and from less than 10 (station 6) to $132 \mu \mathrm{g} / \mathrm{L}$ (station 4) in the hypolimnion. During 2004-06, median zinc concentrations ranged from 2 (station 6) to $55 \mu \mathrm{g} / \mathrm{L}$ (station 4) in the euphotic zone and from 2 (station 6) to $78 \mu \mathrm{g} / \mathrm{L}$ (station 4) in the hypolimnion.

A distinct spatial difference in total zinc concentrations is evident as shown in figure 8. The lowest median values are from station 6 which was far from the influence of the trace-metal-rich inflow of the Coeur d'Alene River. Although station 5 also would appear to be out of the influence of the
Coeur d'Alene River, total zinc concentrations shown in figure 8 indicate otherwise. The three deep stations are directly influenced by the inflow plume of the Coeur d'Alene River and exhibited significantly higher total zinc concentrations than the two shallower stations. Concentrations at station 4 are slightly but statistically higher than all other stations.

At all pelagic stations except station 6, total cadmium and total lead concentrations decreased significantly from 1991-92 to 2004-06. However, as stated previously, robust temporal comparisons for cadmium and lead are hampered by a substantial decrease in reporting limit in the 2004-06 study. Median cadmium and lead concentrations were significantly higher in the hypolimnion than in the euphotic zone at every station except station 6 , where no significant stratification was detected regarding cadmium. As with zinc, the three deep stations exhibited significantly higher total cadmium and total lead concentrations than the two shallow stations; the highest total cadmium and total lead concentrations were measured at station 4.

Total cadmium was not detected in any of the blank samples submitted during the 2004-06 study; however, total lead and total zinc were detected in 24 and 19 percent, respectively, of the blank samples. Field notes recorded during one of the total lead and total zinc detections (April 2005) state that pieces of a rubber seal in the grab sampling device were in the blank sample water during sample processing. The sampling device was soon replaced. Trace metals concentrations in samples collected around this time may be biased high. Mean relative standard deviations in replicate sample data were 2 percent for total cadmium, 3 percent for total lead, and 5 percent for total zinc. Therefore, variability induced during sample processing and analysis was low for these constituents. 


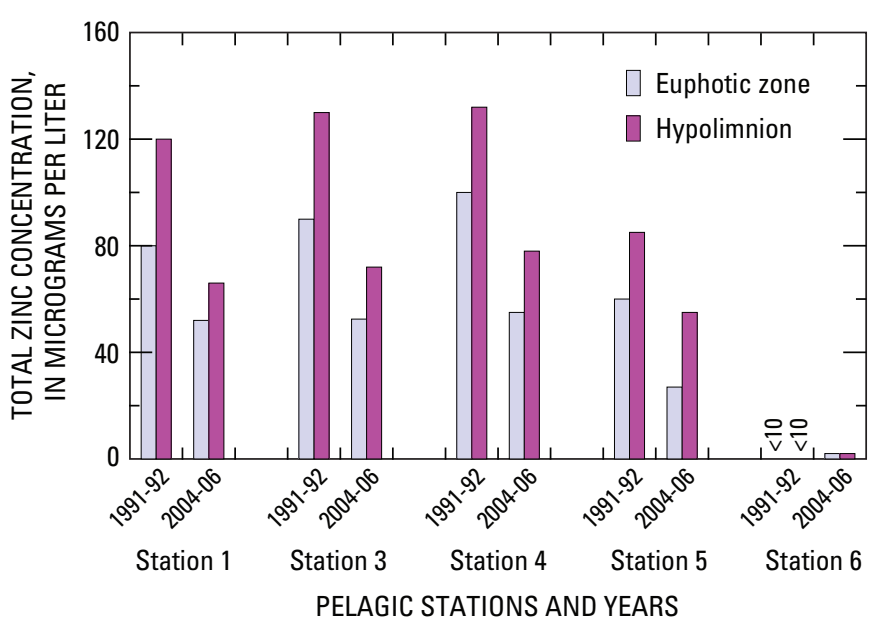

Figure 8. Median concentrations of total zinc in euphotic zone and hypolimnion at five pelagic stations, Coeur d'Alene Lake, Idaho, calendar years 1991-92 and water years 2004-06.

\section{Pelagic and Littoral Water Quality}

The 1991-92 study included two littoral sampling events and the 2004-06 study included eight sampling events. To compare pelagic and littoral water quality between the two studies, only samples collected during the same weeks were compared. For pelagic and littoral comparisons, the latter study period is termed " $2004-05$ " because comparison data were not collected during the same weeks in water year 2006. Mutual constituents sampled between littoral and pelagic stations during the two studies included total phosphorus, chlorophyll- $a$, and zinc. Comparisons were made using two methods:

- Constituent concentrations at the pelagic euphotic zone and littoral stations were compared as a whole for common sampling weeks in September 1991, August 1992, August 2004, and July 2005. Both “NS” and "S" littoral stations were included in the comparison; however, total zinc was the only constituent sampled and evaluated at the "S" stations. Data were compared using the Mann-Whitney hypothesis test because all data during these periods were reported greater than the reporting limit. Concentrations were compared by station type (pelagic or littoral) and between study periods by station type.

- Constituent concentrations at each pelagic station (euphotic zone) and at the corresponding closest littoral stations for the common sampling weeks were paired and tested using the Wilcoxon Signed-Ranks test. For example, constituent concentrations at pelagic station 1 are compared with concentrations at three nearby littoral stations, NS10, NS11, and NS12. Paired littoral stations were selected based on spatial proximity to the pelagic station and based on hydrologic knowledge of the area. "NS" and "S" littoral stations were included in the comparison; however, total zinc was the only constituent sampled and evaluated at the "S" stations. All comparison data were reported greater than the reporting limit.

Comparison 1 indicated that when data sets were compared as a whole, median total phosphorus concentrations were significantly lower in the littoral zone than in the pelagic euphotic zone for weeks sampled in 2004-05. Median total zinc concentrations were significantly lower in the littoral zone than in the pelagic euphotic zone for weeks sampled in 1991-92. In all other cases, total phosphorus, chlorophyll-a, and total zinc concentrations were statistically similar for dates sampled in both study periods. Zinc concentrations for the littoral zone and pelagic euphotic zone in the 2004-05 study decreased significantly from the 1991-92 study.

Comparison 2 indicated that total phosphorus, chlorophyll- $a$, and total zinc concentrations are statistically similar between the pelagic stations and their closest littoral stations on the same weeks sampled. Table 8 presents the median values and ranges for each constituent for each pelagic station and its closest paired littoral stations. A true comparison at station 6 could be made only for total zinc concentrations because chlorophyll- $a$ and total phosphorus were not collected at any of the closest littoral stations. However, chlorophyll- $a$ and total phosphorus concentrations were significantly higher and total zinc concentrations were significantly lower at station 6 than at NS1 (near station 5), the closest littoral station where all three constituents were collected. This observation along with observations previously stated in this report regarding concentration gradients for nutrients and metals, indicate that water-quality conditions at station 5 (and corresponding littoral stations) are slightly different than at station 6 .

Because statistically significant differences were determined in some analyte concentrations among pelagic stations, comparison 2 provides a more valid determination than comparison 1 of the difference between littoral and pelagic water quality because use of this method pairs each pelagic station with the respective littoral area. Additionally, any error introduced by temporal variation was decreased because pelagic samples were compared only with littoral samples collected during the same week.

\section{Physical Limnological Processes}

Focused limnological studies of Coeur d'Alene Lake were conducted between the 1991-92 and 2004-06 studies and included many variables that were sampled in the 1991-92 and 2004-06 studies. These post-1992 studies benefited the design of the 2004-06 study and added spatial and temporal information for many variables. The limnological basis for sampling the lake during the 2004-06 study (table 2) recognized the important role played by physical limnological processes in determining how the lake may be affected in the future by watershed-remediation activities associated with the Bunker Hill Superfund Site OU3 ROD and Lake Management Plan. 
Table 8. Comparisons of medians and ranges of total phosphorus, chlorophyll-a, and total zinc concentrations at pelagic and paired littoral stations on common weeks sampled, Coeur d'Alene Lake, Idaho, water years 2004-05.

[Abbreviations: $\mu \mathrm{g} / \mathrm{L}$, microgram per liter; <, less than; -, not analyzed]

\begin{tabular}{|c|c|c|c|c|c|c|}
\hline \multirow[t]{2}{*}{ Stations } & \multicolumn{2}{|c|}{$\begin{array}{c}\text { Total phosphorus } \\
\text { concentration ( } \mu \mathrm{g} / \mathrm{L})\end{array}$} & \multicolumn{2}{|c|}{$\begin{array}{c}\text { Chlorophyll- } a \text { concentration } \\
(\mu \mathrm{g} / \mathrm{L})\end{array}$} & \multicolumn{2}{|c|}{$\begin{array}{c}\text { Total zinc concentration } \\
(\mu \mathrm{g} / \mathrm{L})\end{array}$} \\
\hline & Median & Range & Median & Range & Median & Range \\
\hline \multicolumn{7}{|c|}{ Station 1} \\
\hline Pelagic station 1 & 6 & $2-11$ & 1.7 & $0.4-2.7$ & 55 & $34-65$ \\
\hline Littoral station NS10 & 5 & $3-14$ & 1.7 & $0.58-3.5$ & 52 & 34-98 \\
\hline Littoral station NS11 & 7.5 & $3-15$ & 1.2 & $0.61-2.0$ & 48 & 34-97 \\
\hline Littoral station NS12 & 5 & $3-8$ & 1.2 & $0.83-3.4$ & 52 & 31-83 \\
\hline \multicolumn{7}{|c|}{ Station 3} \\
\hline Pelagic station 3 & 6 & $2-10$ & 1.4 & $<0.1-2.8$ & 54 & $36-75$ \\
\hline Littoral station NS6 & 4.5 & $3-23$ & 1.4 & $0.38-2.1$ & 58 & $36-77$ \\
\hline Littoral station NS7 & 4 & $3-13$ & 1.4 & $0.39-2.1$ & 66 & $43-100$ \\
\hline Littoral station NS8 & 5.5 & 5-14 & 1.4 & $0.4-2.1$ & 52 & $32-106$ \\
\hline Littoral station NS9 & 4.5 & $3-14$ & 1.1 & $0.78-1.6$ & 55 & 39-86 \\
\hline \multicolumn{7}{|c|}{ Station 4} \\
\hline Pelagic station 4 & 5 & $3-12$ & 1.5 & $0.2-2.4$ & 54 & 42-82 \\
\hline Littoral station NS3 & 6.5 & 5-15 & 1.2 & $0.45-2.1$ & 55 & 37-94 \\
\hline Littoral station NS4 & 6 & $4-12$ & 1.0 & $0.86-2.6$ & 56 & $36-83$ \\
\hline Littoral station NS5 & 5 & $3-16$ & 1.2 & $0.59-2.3$ & 54 & $38-74$ \\
\hline \multicolumn{7}{|c|}{ Station 5} \\
\hline Pelagic station 5 & 10 & $7-31$ & 1.4 & $0.7-2.7$ & 36 & $3-61$ \\
\hline Littoral station NS1 & 11.5 & $7-27$ & 1.2 & $0.33-4.8$ & 19 & $6-90$ \\
\hline Littoral station NS2 & 7 & 5-15 & 1.2 & $0.46-3.5$ & 44 & $13-77$ \\
\hline \multicolumn{7}{|c|}{ Station 6} \\
\hline Pelagic station 6 & 17 & $10-36$ & 2.9 & $0.5-5.6$ & 2 & $1-4$ \\
\hline Littoral station S5 & - & - & - & - & 2 & $1-2$ \\
\hline Littoral station S6 & - & - & - & - & 2 & $2-2$ \\
\hline Littoral station NS1 & 10 & $7-27$ & 0.9 & $0.3-2.3$ & 18 & $6-90$ \\
\hline
\end{tabular}

Two recent reports (URS Greiner, Inc., and CH2M-Hill, Inc., 2001 and Woods, 2004), noted the importance of physical limnological processes in the fate and transport of constituents and, by extension, water-quality conditions in Coeur d'Alene Lake. Those processes include, but are not limited to, lake hydraulic residence time, wind-generated circulation, and in-lake routing of inflow plumes.

\section{Hydraulic Residence Time}

Surface-water runoff from a drainage basin commonly is the primary source of inflow to most lakes; ground-water inflow and direct precipitation on the lake surface usually are of much smaller magnitude. The rate at which water enters and leaves a lake affects the amount of turbulence within the lake water column, both in the horizontal and vertical dimensions. Limnologists have long used the ratio of inflow rate to lake volume, commonly termed flushing rate (Ryding and Rast, 1989), to quantify this physical limnological process. As flushing rate increases, the hydrologic influence on the lake from the drainage basin also increases because the lake volume is frequently replaced. The inverse of flushing rate is retention time, which represents the time theoretically needed to fill a lake if the lake were empty. If lake volume is divided by lake outflow rate instead of inflow rate, then the time needed to empty the lake, the hydraulic residence 
time, is obtained. On an annual basis, retention time and hydraulic residence time often are comparable. Hydraulic residence time was selected for analysis in this report because outflow rates for Coeur d'Alene Lake have been measured for many years; measurements of the sum of inflow rates for all significant inflow sources are rare for most lakes. Although retention time and hydraulic residence time are theoretical concepts, the processes that they incorporate are important for understanding fate and transport of constituents in lakes. In years of greater than normal inflow and outflow, increased water column turbulence and advective transport of constituents can be expected. Conversely, years of less than normal inflow and outflow produce less water column mixing and may increase the constituents trapped in the lake.

The hydraulic residence time for Coeur d'Alene Lake is 0.50 year based on a normal full-pool volume of $2.8 \mathrm{~km}^{3}$ divided by the mean annual outflow rate of $5.6 \mathrm{~km}^{3} / \mathrm{yr}$. Outflow statistics for the lake were derived for a 93-year period of record (1913-2006) for the USGS gaging station on Spokane River near Post Falls, Idaho (U.S. Geological Survey, 2007). During that period of record, however, annual mean outflow volume varied widely. For the minimum outflow rate of $1.9 \mathrm{~km}^{3} / \mathrm{yr}$, the hydraulic residence time increased to 1.5 years; conversely, for the maximum outflow rate of $10.5 \mathrm{~km}^{3} / \mathrm{yr}$, hydraulic residence time decreased to 0.27 year. This range of hydraulic residence times and historical outflow rates indicate that the lake volume could be replaced in as few as 98 days or as many as 548 days. This range also represents an index of the physical limnological process of water column turbulence and the presumed relation with hydraulic residence time. Retention of constituents delivered from the drainage basin to Coeur d'Alene Lake is expected to decrease as hydraulic residence time decreases. In addition to inter-annual variability, outflow from the lake varies intra-annually in response to climate conditions in the drainage basin. During the 1913-2006 period of record, the smallest monthly mean outflow of $0.07 \mathrm{~km}^{3} / \mathrm{mo}$ was in August, whereas the largest monthly mean outflow of $1.3 \mathrm{~km}^{3} / \mathrm{mo}$ was in May. Based on these outflow rates, constituents inflowing to the lake are more likely to be retained in August when water column turbulence and water outflow are minimal.

Although insight was gained into the relation of inflow or outflow magnitude on the generation of turbulence and advective transport within lakes, the concepts of retention and hydraulic residence times remain theoretical because lakes rarely are filled or emptied. The two concepts are best suited for general comparisons among lakes representing wide ranges of retention and hydraulic residence times.

\section{Wind-Generated Circulation}

The physical, chemical, and biological responses of a lake to the delivery of water and associated constituents from the drainage basin are closely tied to shape, exposure to wind, and depth of the lake. A long, narrow lake shape, like that of Coeur d'Alene Lake, is more prone to channelized flow along its major axis. Shape and surface area of a lake are determinants of wind exposure. Increased wind exposure enhances the development of large-scale turbulent processes such as surface waves and internal seiches, which can displace large masses of water in the horizontal and vertical dimensions, important mechanisms for water column mixing. Deep lakes, such as Coeur d'Alene Lake, are less prone to turbulent, full-depth mixing by wind energy, so lakebed sediments are less likely to be periodically re-suspended except perhaps by internal waves near the thermocline. The low frequency of turbulent, full-depth mixing in deep lakes also restricts the exchange of dissolved, colloidal, and particulate constituents between the upper and lower water columns.

\section{Routing of Inflow Plumes}

The movement of riverine inflows within a lake can be quite complex because of lake characteristics such as shape, depth, and temporal and spatial differences in density between riverine and lake water. Overflow, interflow, and underflow are three generalized methods of inflow plume routing (Fischer and others, 1979). Overflow occurs if the inflow plume is warmer (less dense) than the lake; river water floats on the lake surface. Interflow occurs when the inflow plume is colder than the lake upper water column but is warmer than the lower water column; interflow is routed to the lake depth where the temperature, or density, of the inflow plume and lake are equal. Underflow occurs when the inflow plume is colder than, or near the temperature of, the lake lower water column. Turbulence at the interface of the inflow plume and the lake mixes the two water masses until thermal equilibrium is reached. The spatial extent of inflow plume routing is highly dependent on the magnitude of riverine discharge. Riverine inflows generated by snowmelt runoff and floods can penetrate farther into the receiving lake because the large inflow volumes produced by such events increase advective transport.

The fate and transport of constituents such as nutrients, trace metals, and sediment within and occasionally through Coeur d'Alene Lake are highly dependent on inflow plume routing of the two primary inflow sources, the Coeur d'Alene 
and St. Joe Rivers. Inflow plume routing was evaluated using data from the 1991-92 and 2004-06 limnological studies as well as data from several other studies of the lake. For the 1991-92 study, available data included water temperatures for the two rivers (Harenberg and others, 1992; 1993) and numerous full-depth profiles of water temperatures conducted for most months at pelagic stations (Woods and Beckwith, 1997). An inflow plume routing evaluation also was evaluated for water year 1999 using similar water-temperature data; however, pelagic water column profiles were conducted only during June through October at pelagic stations 1, 3, 4, and 5 (URS Greiner, Inc., and CH2M Hill, Inc., 2001).

Forty-four comparisons of inflow and lake temperatures reported for 1991-92 and 1999 (URS Greiner, Inc., and CH2M Hill, Inc., 2001) indicated that overflow was the most common mode of inflow plume routing, occurring in about 60 percent of the comparisons (URS Greiner, Inc., and CH2M Hill, Inc., 2001). Interflow or underflow each occurred in about 20 percent of the comparisons. Overflow occurred in all months except October, November, and December; during those 3 months, underflow was the most likely mode of inflow plume routing. Interflow tended to occur during spring or autumn when the lake was likely transitioning into or out of thermal stratification. Inflow volume also was evaluated as part of the 44 comparisons because of its affect on the spatial extent of inflow plume routing. At small inflows, the influence of the plume on the lake was diminished by rapid mixing and equilibration of riverine and lake temperatures; the opposite was true for large inflows. Underflows tended to be associated only with small inflows, typical for October through December. Underflows occurred during that 3-month period because the Coeur d'Alene and St. Joe Rivers cooled more rapidly than the lake, which has a much greater capacity to store and retain heat captured during the summer months. Overflows occurred over a wide range of inflows because the Coeur d'Alene and St. Joe Rivers each have lengthy backwater-affected reaches that capture a large amount of solar radiation.

During June 1999, USGS scientists using specialized water-quality instrumentation and water column sampling methods tracked discharge and chemistry of the Coeur d'Alene and St. Joe River inflow plumes into and through Coeur d'Alene Lake. The short-term study sought to answer two questions: (1) Can riverine inflows and associated chemical nature be clearly identified within the lake? (2) Do sediments, nutrients, and trace metals carried by riverine inflows travel far enough into the lake to be discharged out of the lake into the Spokane River? The field work was conducted during June 2-3, 1999, at pelagic stations $1-5$ in addition to three stations at the mouths of the Coeur d'Alene and St. Joe Rivers and at the lake outlet to the Spokane River. Study results clearly identified the riverine inflows as a combination of overflow and interflow within the upper 5-13 $\mathrm{m}$ of the lake, from station 4 and northward to the lake outlet (URS Greiner, Inc., and CH2M Hill, Inc., 2001). Much of the lake south of station 4 is shallow enough to allow fulldepth mixing of the two riverine inflows. Light transmission, conductivity, and concentrations of lead, zinc, and nitrogen differed substantially between the riverine inflows and lake water. Lead concentrations delivered by the Coeur d'Alene River were higher than concentrations in lake water. Zinc concentrations, delivered almost exclusively by the Coeur d'Alene River, were lower than concentrations in lake water. Light transmission, conductivity, and nitrogen concentrations in riverine water also were lower than concentrations in lake water. The chemical nature of water exiting the lake to the Spokane River during the June 1999 experiment was more closely related to riverine inflows than to lake water; however, this is not expected to be true throughout the year.

Numerous riverine inflow temperatures and water column profiles of water temperature were available for water years 2004 and 2005 during the 2004-06 study to evaluate inflow plume routing. Table 9 lists 15 riverine inflow temperatures measured within two weeks of a limnological sampling trip in water years 2004 and 2005, similar to a table presented in URS Greiner, Inc., and CH2M Hill, Inc. (2001). One measurement is shown for which there was no sampling data. The water temperatures and discharges of the Coeur d'Alene and St. Joe Rivers were compared to the range of water column temperatures at pelagic station 3 , the deepest area in the lake. Of the 15 comparisons, 7 indicated overflow, 6 indicated interflow, and 2 indicated underflow (table 9). Underflows occurred in December of both years because inflowing rivers cooled faster than the lake, which had a much larger heat storage capacity. Interflows occurred in early April, May, and June and in early September 2004 and in late March and mid-May 2005. The predominance of interflows during spring months was partly due to more rapid warming of the inflowing rivers than the lake, which was emerging from winter cooling. Overflows were recorded during October of both years, as late summer heating kept riverine temperatures similar to lake temperatures. For summer months, overflow was recorded only in July 2004 and during June, July, and August 2005. Cold $\left(2.0-2.3^{\circ} \mathrm{C}\right)$ riverine water that entered the lake in February 2005 during a period of inverse stratification (lake water at $3.4^{\circ} \mathrm{C}$ with maximum density, underlying colder, less dense water) caused an overflow condition. 
Table 9. Inflow plume routing based on comparison of riverine inflow temperatures and water column temperature ranges at pelagic station 3, Coeur d'Alene Lake, Idaho, water years 2004-05.

[Station locations are shown in figure 1. St. Joe River (USGS gaging station 12415140); Coeur d'Alene River (USGS gaging station 12413860). Abbreviations: ${ }^{\circ} \mathrm{C}$, degrees Celsius; $\mathrm{m}^{3} / \mathrm{s}$, cubic meter per second; USGS, U.S. Geological Survey; -, not analyzed]

\begin{tabular}{|c|c|c|c|c|c|c|c|c|c|}
\hline $\begin{array}{c}\text { Date of } \\
\text { river } \\
\text { sampling }\end{array}$ & \multicolumn{2}{|c|}{ St. Joe River } & \multicolumn{2}{|c|}{ Coeur d'Alene River } & \multicolumn{2}{|c|}{ Pelagic station 3} & \multicolumn{3}{|c|}{ Inflow plume routing } \\
\hline \multicolumn{10}{|c|}{ Water year 2004} \\
\hline 04-06 & 6.5 & 195 & 6.8 & 210 & $04-14$ & $4.2-9.3$ & & $\mathrm{X}$ & \\
\hline $05-08$ & 8.3 & 195 & 9.4 & 108 & $05-18$ & $4.9-12.9$ & & $\mathrm{X}$ & \\
\hline $06-08$ & 10.8 & 139 & 11.8 & 87.8 & $06-22$ & $5.7-18.1$ & & $\mathrm{X}$ & \\
\hline 07-19 & 21.8 & 34.0 & 22.9 & 22.1 & $07-20$ & $5.9-22.6$ & $\mathrm{X}$ & & \\
\hline 09-01 & 17.4 & 14.2 & 17.3 & 4.39 & 08-25 & $6.1-21.1$ & & $\mathrm{X}$ & \\
\hline $12-13$ & 3.0 & 180 & 3.3 & 312 & $12-04$ & $6.7-7.4$ & & & $\mathrm{X}$ \\
\hline $02-07$ & 2.0 & 79.3 & 2.3 & 79.3 & $01-25$ & $3.4-2.4$ & $\mathrm{X}$ & & \\
\hline 03-14 & 6.0 & 51.0 & 7.2 & 34.0 & - & - & & & \\
\hline $03-30$ & 3.3 & 227 & 3.5 & 232 & 04-07 & $4.2-4.5$ & & $\mathrm{X}$ & \\
\hline $05-12$ & 8.3 & 178 & 11.3 & 73.6 & $05-24$ & $5.2-12.5$ & & $\mathrm{X}$ & \\
\hline $06-27$ & 19.1 & 42.5 & 18.8 & 21.0 & $06-14$ & $5.2-14.6$ & $\mathrm{X}$ & & \\
\hline 07-18 & 20.3 & 18.7 & 22.4 & 16.1 & $07-20$ & $5.5-21.3$ & $\mathrm{X}$ & & \\
\hline $08-25$ & 20.8 & 7.65 & 21.0 & 3.96 & 09-01 & $5.7-19.9$ & $\mathrm{X}$ & & \\
\hline
\end{tabular}

\section{Benthic Flux}

The primary focus of the 1991-92 study was on nutrients and lake productivity; collection of trace metal samples from the lake water column was less frequent and at fewer depths. However, lakebed sediments also were sampled during this period for characterization of concentration, partitioning, and environmental availability of selected trace metals (Horowitz and others, 1993; 1995a; 1995b; 2001). These additional sediment studies estimated that 75 million metric tons of metals-enriched sediments cover about 85 percent of the bottom of Coeur d'Alene Lake. These sediments range in thickness from 17 to more than $119 \mathrm{~cm}$. Horowitz and others (1993) reported mean concentrations of arsenic (151 mg/kg), cadmium (62 mg/kg), lead (1,900 mg/kg), mercury (1.8 $\mathrm{mg} / \mathrm{kg})$, and zinc $(3,600 \mathrm{mg} / \mathrm{kg})$ in lakebed surface sediments in Coeur d'Alene Lake. Naturally occurring background concentrations in lakebed sediments were reported for arsenic ( $5 \mathrm{mg} / \mathrm{kg}$ ), cadmium (3 mg/kg), lead (24 mg/kg), mercury $(0.05 \mathrm{mg} / \mathrm{kg})$, and zinc $(110 \mathrm{mg} / \mathrm{kg})$ (Horowitz and others,
1993). Metals-enriched sediments in Coeur d'Alene Lake generally are extremely fine-grained and are susceptible to remobilization by river- and wind-induced lake currents.

Although eutrophication by nutrients and contamination of lakebed sediments by trace metals may have appeared to be unrelated water-quality problems for Coeur d'Alene Lake, the potential development of water column anoxia near the lakebed could release nutrients and trace metals from lakebed sediments into the overlying water column. When anoxia develops, a well-known consequence of eutrophication, reductive dissolution of metal oxides, such as iron and manganese, can occur in lakebed sediments and the hypolimnion (Brezonik, 1994). At dissolved-oxygen concentrations less than $1 \mathrm{mg} / \mathrm{L}$, iron-phosphate complexes may become unstable and dissolve and release phosphorus from lakebed sediments into the hypolimnion (Jones and Bowser, 1978; Baccini, 1985). Horowitz and others (1993) reported that most lakebed trace metals in Coeur d'Alene Lake were associated with iron oxides. Under anoxia, the reductive dissolution of iron oxides could release trace metals into the 
water column of the lake. The potential development of anoxia in Coeur d'Alene Lake prompted a study by the USGS in 1987. Hypolimnetic dissolved oxygen concentrations as low as $4 \mathrm{mg} / \mathrm{L}$ were detected during late summer in the deep northern basin of the lake (Woods, 1989).

Based on published literature related to anoxic releases of constituents from lakebed sediments, the 1991-92 study did not anticipate releases of nutrients and trace metals from the lakebed sediments because hypolimnetic dissolved oxygen concentrations exceeded $1 \mathrm{mg} / \mathrm{L}$. The study's focus was oriented toward understanding the lake assimilative capacity for nutrients to maintain adequate concentrations of hypolimnetic dissolved oxygen. However, additional studies done in Coeur d'Alene Lake by N.S. Simon (U.S. Geological Survey, written commun., 1993), Kuwabara and others (2000; 2003; 2006), and Winowiecki (2002) after the 1991-92 study detected the presence of a benthic flux, the movement of constituents into and out of lakebed sediments, even in the presence of hypolimnetic dissolved oxygen concentrations greater than $1 \mathrm{mg} / \mathrm{L}$.

Benthic fluxes define the transport of dissolved constituents across the sediment-water interface. In the absence of advection, this transport primarily is a function of concentrations in the overlying water and in porewater just below the interface (the chemical gradient) and the molecular or eddy diffusion coefficients for the constituents of interest. Benthic fluxes have both direction and magnitude. The direction indicates whether the sediment supplies or removes dissolved constituents to or from the overlying water. Sediments act as a source when dissolved-constituent concentrations in the porewater are greater than in the overlying water (positive flux) or a sink when dissolvedconstituent concentrations in the overlying water are greater than in the porewater (negative flux). The magnitude of benthic fluxes depends on the steepness of the chemical gradient and the transport mechanism (molecular compared to eddy diffusion); the magnitude can be used to determine the relative importance of sediments as a source or sink for dissolved constituents in a lake.

Balistrieri (1998) evaluated the benthic flux studies of N.S. Simon (U.S. Geological Survey, written commun., 1993) and Winowiecki (2002) conducted in September 1992. Constituent concentrations in water overlying sediments and in porewater were used by Balistrieri (1998) to calculated benthic fluxes using Fick's First Law, which assumes that benthic fluxes were controlled by molecular diffusion across the sediment-water interface. Porewater was collected by N.S. Simon (U.S. Geological Survey, written commun., 1993) and Winowiecki (2002) using diffusion-controlled equilibrator samplers, also known as peepers or dialyzers, which were inserted into the lakebed sediments by divers. Balistrieri
(1998) noted that oxidation of the porewater samples likely occurred during collection and handling of the samples. This oxidation probably affected the concentrations of certain metals in the porewater (iron and metals that adsorb to iron-oxide phases), and thereby, influenced the benthic flux calculations.

The benthic flux study of Coeur d'Alene Lake conducted in August 1999 and discussed by Kuwabara and others (2000) used an in situ benthic flux chamber that isolated a volume of water overlying the sediment and periodically sampled constituent concentrations in the chamber. Fluxes were calculated as a function of time on the basis of changes in dissolved-constituent concentrations during deployment of the chamber. Using this method, no assumption is required about the mechanism of transport (molecular or eddy diffusion) to determine fluxes.

The results of benthic flux measurements from the chamber method are summarized in table 10 for dissolved cadmium, iron, lead, manganese, and zinc. Each value is reported as micrograms per square centimeter of lakebed surface per year $\left(\mu \mathrm{g} / \mathrm{cm}^{2} / \mathrm{yr}\right)$ moving out of the lakebed sediments. The in situ benthic flux chamber method is considered more representative of conditions in Coeur d'Alene Lake, compared to the peeper method by Winowiecki (2002), because the in situ benthic flux chamber method trapped an existing parcel of lakebed sediment, associated porewater, and overlying lake water, and measured benthic flux without major alteration of pre-existing conditions. Dissolved oxygen concentrations in the lower hypolimnion of the lake near the experiment stations were consistently high, 8-10 mg/L, during August 1999, and oxygen consumption rates in the chamber measured during the experiment were small, 6.0-9.5 millimoles of oxygen per square meter per day. Water in the chambers did not become anoxic at any point during the experiment (Kuwabara and others, 2000). Therefore, oxygen consumption in the chamber during the experiment did not substantially alter the chemical environment at the sedimentwater interface from ambient conditions.

Based on the in situ benthic flux chamber results listed in table 10, dissolved cadmium, iron, lead, manganese, and zinc had positive fluxes out of the lakebed sediments. The smallest flux was for lead, $1.9 \mu \mathrm{g} / \mathrm{cm}^{2} / \mathrm{yr}$; the largest was for manganese, 3,700 $\mu \mathrm{g} / \mathrm{cm}^{2} / \mathrm{yr}$. Standard error was high (greater than 50 percent) relative to average flux values reported for iron, lead. and manganese (Kuwabara and others, 2000).

The benthic flux of dissolved nutrients and DOC also were measured by the in situ benthic flux chamber method (table 11). The benthic fluxes for orthophosphate, nitrite plus nitrate, ammonia, the sum of nitrite plus nitrate and ammonia (dissolved inorganic nitrogen), and DOC were all positive, indicating movement out of the lakebed sediments. 
Table 10. Benthic flux of dissolved metals measured by an in-situ flux chamber, Coeur d'Alene Lake, Idaho, 1999.

[Station locations are shown in figure 1. Latitude, longitude in degrees, minutes, seconds, North American Datum of 1927 (Kuwabara and others, 2000). Benthic flux: average flux values were determined for multiple samplings of flux chambers at each site. Data from Kuwabara and others (2000). Values rounded to 2 significant figures. Abbreviations: $\mu \mathrm{g} / \mathrm{cm}^{2} / \mathrm{yr}$, microgram per square centimeter per year]

\begin{tabular}{|c|c|c|c|c|c|c|}
\hline \multirow{2}{*}{ Station name } & \multirow{2}{*}{ Latitude, longitude } & \multicolumn{5}{|c|}{ Benthic flux ( $\left.\mu \mathrm{g} / \mathrm{cm}^{2} / \mathrm{yr}\right)$} \\
\hline & & Cadmium & Iron & Lead & Manganese & Zinc \\
\hline Main channel, BF1 & 4730'26", 11651'27" & 3.1 & 180 & 2.4 & 3,700 & 280 \\
\hline Mica Bay, BF2 & 47³6'02", 11649'53" & 2.3 & 110 & 1.9 & 3,000 & 350 \\
\hline
\end{tabular}

Table 11. Benthic flux of nutrients and dissolved organic carbon measured by an in-situ flux chamber, Coeur d'Alene Lake, Idaho, 1999.

[Station locations are shown in figure 1. Latitude, longitude in degrees, minutes, seconds, North American Datum of 1927 (Kuwabara and others, 2000$).$ Benthic flux: average flux values were determined for multiple samplings of flux chambers at each site. Data from Kuwabara and others (2000). Values rounded to 2 significant figures. Abbreviations: $\mu \mathrm{g} / \mathrm{cm}^{2} / \mathrm{yr}$, microgram per square centimeter per year]

\begin{tabular}{|c|c|c|c|c|c|c|}
\hline $\begin{array}{c}\text { Station } \\
\text { name }\end{array}$ & Latitude, longitude & \multicolumn{5}{|c|}{ Benthic flux, $\left(\mu \mathrm{g} / \mathrm{cm}^{2} / \mathrm{yr}\right)$} \\
\hline Main channel, BF1 & 47³0'26", 11651'27" & 7.2 & 160 & 58 & 220 & 2,700 \\
\hline Mica Bay, BF2 & 47³6'02", 11649'53" & 22 & 210 & 110 & 320 & 1,800 \\
\hline
\end{tabular}

The smallest flux was for orthophosphate, $7.2 \mu \mathrm{g} / \mathrm{cm}^{2} / \mathrm{yr}$; the largest was for DOC, 2,700 $\mu \mathrm{g} / \mathrm{cm}^{2} / \mathrm{yr}$. Kuwabara and others (2000) determined that molecular diffusion was likely the dominant transport mechanism for constituents across the sediment-water interface in Coeur d'Alene Lake.

The flux of dissolved constituents across the sedimentwater interface is a result of the coupling of physical, chemical, and biological processes (Santschi and others, 1990). Biologically mediated chemical reactions can mobilize dissolved constituents from solid phases within the lakebed sediments, thereby allowing transport by molecular and eddy diffusion. Oxidation of organic matter in the upper sediments of aquatic environments can affect the partitioning of certain constituents between sediment and porewater and produces nutrients such as ammonia and orthophosphate that are needed for phytoplanktonic production. Studies of freshwater and marine sediments indicate that the oxidation of organic matter proceeds using a thermodynamically predictable sequence of oxidants: oxygen, nitrate, manganese oxyhydroxides, ferric oxyhydroxides, and sulfate (Froelich and others, 1979; Berner, 1980; Pedersen and Losher, 1988; and Luther and others, 1998). These reactions are reflected in the composition of porewater as a function of depth. With increasing depth, oxygen and nitrate disappear followed by the appearance of nitrite, ammonia, and dissolved manganese and iron, then sulfate disappears. Oxygen is the primary oxidant of organic matter in the oxic zone. Suboxic conditions occur when oxygen concentrations are very low and nitrate, manganese oxyhydroxides, and ferric oxyhydroxides are used as oxidants. The location of this zone in the upper sediments of Coeur d'Alene Lake is of particular interest with respect to metals because the reduction of manganese and ferric oxyhydroxides can result in the release of associated trace metals (cadmium, lead, and zinc) into the dissolved phase. The absence of oxygen and oxidation of organic matter by sulfate characterize anoxic conditions. Sulfate reduction results in the production of sulfide. This sulfide appears either in porewater or is precipitated as a metal sulfide phase, if there are sufficient concentrations of dissolved metals, primarily iron. The depth scale where these reactions occur can be large (meters) or small (millimeters to centimeters) depending on the supply of organic matter, bottom-water anoxia, and sedimentation rates. If these reactions are compressed into the upper few centimeters just below the sediment-water interface, then concentrations of oxygen, nitrate, and sulfate should be lower in porewater just below the interface, relative to concentrations in the overlying water because of organic matter diagenesis. Thus, the direction of 
benthic fluxes for these species (oxygen, nitrate, and sulfate) should be into the sediment. Porewater profiles of sulfate within the upper $30 \mathrm{~cm}$ of Coeur d'Alene Lake sediments indicate that the transition from oxic, through suboxic, to anoxic conditions exists, depending on location, either within the upper $1 \mathrm{~cm}$ or the upper $2-5 \mathrm{~cm}$ just below the interface (Balistrieri, 1998). Kuwabara and others (2000) measured oxygen benthic fluxes that ranged from -6.0 to -9.5 millimoles of oxygen per square meter per day, consistent with oxygen consumption by the sediments. Analytical methods employed by Kuwabara and others (2000) did not separate nitrate and nitrite concentrations, so no benthic fluxes were determined for nitrate alone.

In contrast, oxidation of organic matter produces nitrite, ammonia, orthophosphate, and dissolved manganese and iron. The concentrations of these constituents should be higher in porewater relative to the overlying water. Thus, the direction of benthic fluxes for these species should be out of the sediments if no other reactions (adsorption of phosphorus to iron oxides) trap them in the sediments. For example, when a thin oxic layer overlies a suboxic or anoxic layer, dissolved iron produced in the suboxic zone can diffuse into the oxic zone to be oxidized and precipitated as solid-phase iron oxyhydroxides. These iron oxides could then adsorb dissolved orthophosphate. This scenario would effectively trap iron and orthophosphate in the sediment and prevent them from diffusing into the overlying water. However, benthic flux data strongly indicate that sediments in Coeur d'Alene Lake act as a source of dissolved iron and orthophosphate, as well as ammonia and manganese, to the overlying water (tables 10 and 11). Overall, however, there is a net sedimentation of these constituents to lake sediments when they are associated with particulate material, as demonstrated in the lake mass balance calculations for metals (table 5).

Oxidation of organic matter can indirectly mobilize or sequester constituents such as cadmium, lead, and zinc. If these trace metals are predominantly supplied to the sediments in particulate form and in association with iron and manganese oxides, then the reduction of iron and manganese oxides during organic matter oxidation (after all available dissolved oxygen and nitrate are exhausted and reduced) results in the release of not only dissolved iron and manganese, but all other trace metals associated with those phases. The dissolved trace metals can be either transported by molecular or eddy diffusion across the sediment-water interface, or if sufficient concentrations of sulfide are present, be precipitated or co-precipitated as authigenic metal-sulfide phases. Although authigenic sulfides may be forming in Coeur d'Alene Lake, as reported by Harrington and others (1998), most benthic flux data indicate that sediments in Coeur d'Alene Lake act as a net source of dissolved cadmium, lead, and zinc to the overlying water (table 10).

The 2004-06 limnological study sought to increase understanding of benthic flux by identifying it as an important water-quality issue for Coeur d'Alene Lake through the studies by Horowitz and others (1993, 1995a, 1995b); Balistrieri (1998); Harrington and others (1998); Kuwabara and others (2000); and Woods (2004). The logistical difficulties involved in installation and retrieval of diffusion-controlled samplers or in situ flux chambers prompted the design of a boat deployed, modified gravity coring device that could retrieve undisturbed samples of the sediment-water interface. With this device, up-to-date information on benthic flux was added in the 2004-06 study. Interpretation of the data generated by the new sampling device comes with some caveats. First, the device was designed to monitor changes in the chemical composition of water immediately above the lakebed sediments over time and to compare those results to concurrently sampled water $1 \mathrm{~m}$ above lakebed sediments. Second, the device did not measure gradients in the pore water or at the sedimentwater interface; the analytical results for the small volume sampled represent the net effect of all processes operating at the sediment-water interface. Third, no attempt was made to control oxidation of samples during sample processing; as such, the partitioning between dissolved and particulate phases cannot be assessed.

A summary of the analytical results obtained on 22 sampling trips during the 2004-06 study are listed in table 12 for 8 constituents. All samples were obtained at pelagic station 4 , near the main channel in situ flux chamber study reported by Kuwabara and others (2000). Table 12 lists constituents with significantly higher median concentrations in sedimentwater interface samples than those in lower hypolimnetic samples (collected $1 \mathrm{~m}$ above the lakebed). Samples were compared using the paired Wilcoxon Signed-Ranks Test. No significant difference was apparent for paired median concentrations of dissolved inorganic nitrogen. Paired median concentrations of total phosphorus, dissolved organic carbon, total cadmium, total zinc, total iron, total lead, and total manganese were significantly higher in the sediment-water interface than in the lower hypolimnion. Of these seven analytes, the differences between the sediment-water interface and lower hypolimnion were, from smallest to largest: dissolved organic carbon, 1.2 times; total zinc, 1.8 times; total cadmium, 2.7 times; total phosphorus, 3.5 times; total iron, 12 times; total lead, 19 times; and total manganese, 27 times. 
Table 12. Medians and ranges of concentrations of selected constituents measured in lower hypolimnion and near sediment-water interface at pelagic station 4, Coeur d'Alene Lake, Idaho, water years 2004-06.

[Values are in micrograms per liter unless otherwise indicated. Sample type: SWI, sediment-water interface; LH, lower hypolimnion. Abbreviations: mg/L, milligram per liter; n, number of samples]

\begin{tabular}{|c|c|c|c|c|c|}
\hline \multirow{2}{*}{ Constituent and units } & \multirow{2}{*}{$\begin{array}{c}\text { Sample } \\
\text { type }\end{array}$} & \multirow{2}{*}{ Median } & \multicolumn{2}{|c|}{ Range } & \multirow{2}{*}{$\mathbf{n}$} \\
\hline & & & Maximum & Minimum & \\
\hline \multicolumn{6}{|c|}{ No significant difference between SWI and LH } \\
\hline \multirow[t]{2}{*}{ Dissolved inorganic nitrogen } & $\mathrm{LH}$ & 86 & 200 & 36 & 22 \\
\hline & SWI & 92 & 220 & 28 & 22 \\
\hline \multicolumn{6}{|c|}{ SWI significantly greater than LH } \\
\hline \multirow[t]{2}{*}{ Total phosphorus } & LH & 7.5 & 41 & 3.0 & 22 \\
\hline & SWI & 26 & 49 & 6.0 & 22 \\
\hline \multirow[t]{2}{*}{ Dissolved organic carbon, mg/L } & $\mathrm{LH}$ & 1.3 & 1.5 & 1.2 & 12 \\
\hline & SWI & 1.6 & 3.3 & 1.2 & 12 \\
\hline \multirow[t]{2}{*}{ Total cadmium } & LH & .32 & .48 & .22 & 22 \\
\hline & SWI & .85 & 1.6 & .31 & 22 \\
\hline \multirow[t]{2}{*}{ Total zinc } & LH & 76 & 110 & 66 & 22 \\
\hline & SWI & 140 & 340 & 77 & 22 \\
\hline \multirow[t]{2}{*}{ Total iron } & LH & 54 & 310 & 19 & 22 \\
\hline & SWI & 630 & 1,600 & 58 & 22 \\
\hline \multirow[t]{2}{*}{ Total lead } & $\mathrm{LH}$ & 1.8 & 17 & .54 & 22 \\
\hline & SWI & 35 & 120 & 2.5 & 22 \\
\hline \multirow[t]{2}{*}{ Total manganese } & LH & 5.9 & 40 & 2.5 & 22 \\
\hline & SWI & 160 & 830 & 6.6 & 22 \\
\hline
\end{tabular}

\section{Implications of Limnological Studies}

A number of implications can be gleaned from the results of the numerous water-quality monitoring studies in Coeur d'Alene Lake. Coeur d'Alene River is a source of dissolved and particulate phase metals to the lake, and existing lakebed sediments serve as a sink for particulate phase metals and a source of dissolved metals in the lake. Even though efforts are continuing in the Coeur d'Alene River basin to control metals contamination as part of the ROD, conditions in the lake with regard to metals cannot be expected to improve significantly if the river source and bed sediment source are not both addressed. In addition, wind-driven circulation patterns and riverine inflow plumes contribute to the spread of contaminants throughout the lake. Therefore, no part of the lake is immune to contamination.

Although the trophic state of the lake has been classified as oligotrophic or mesotrophic (depending on the variable used for classification) in both the 1991-92 and 2004-06 studies, phosphorus concentrations and lake productivity have increased over time, and nitrogen-to-phosphorus ratios (when detected) appear to have decreased over time. Increased loads of nutrients to the lake (primarily nitrogen and phosphorus) can increase the growth of algae and aquatic plants. When this organic material decomposes, oxygen dissolved in the water is consumed. Depletion of dissolved oxygen concentrations in the bottom waters of the lake could lead to geochemical processes that increase the rate of release of mining associated metals contaminants (such as dissolved arsenic, cadmium, mercury, lead, and zinc) from lakebed sediments, as well as stored nutrients that would stimulate additional plant and algae growth in a self-perpetuating cycle that may be difficult or impossible to interrupt. These processes could increase risks to human health and adversely affect the environment and the economic and social welfare of the community.

Phosphorus limitation is currently keeping biomass low, and results of the ELCOM-CAEDYM simulation model show that diatoms, the current dominant phytoplankton in the lake, are kept in control by toxic levels of zinc (Hipsey and others, 2006; Kuwabara and others, 2006). Zinc loads to the lake would have to decrease more than 1-2 orders of magnitude before any appreciable reduction in zinc toxicity would be noted. However, if nutrient loads continue to increase as zinc loads decrease, phytoplankton dominance in the lake may shift from diatoms (Bacillariophyceae) to a more diverse assemblage of green algae (Chlorophyceae) and nuisance or bloom-forming species of blue-greens (Cyanobacteria) which are more zinc-intolerant (Hipsey and others, 2006). Nutrient load management should be addressed as a component of a Lake Management Plan. 


\section{Future Monitoring and Research Needs}

Water-quality conditions in the lake have a significant effect on lake biota, tourism, recreation, and quality of life for basin residents, including the Coeur d'Alene Indian Tribe. A number of phenomena recorded during the course of USGS and Tribe limnological studies discussed in this report merit further investigation to provide a more comprehensive understanding of the myriad of processes that affect waterquality conditions in Coeur d'Alene Lake.

The ELCOM-CAEDYM model could serve as a valuable tool for Coeur d'Alene Lake managers for simulating the response of the lake to various remediation strategies in the basin. A long-term, comprehensive monitoring plan would allow lake managers to monitor for future changes in waterquality conditions; to track the frequency, duration and extent of anoxia in the lake's hypolimnion; to fill data gaps that could improve ELCOM-CAEDYM; and to measure the lake's response to future remediation measures. Generally, previous monitoring programs have been designed to answer specific questions and have differed in scope, constituents sampled, analytical methods, and timing of sampling. If possible, any future monitoring program would benefit from consistency in terms of space, time, constituents sampled, and analytical methods used.

A possible monitoring program could include monthly sampling of four stations within the pelagic zone (stations 1,4 , 5 , and 6, or a new station between stations 3 and 4 in place of 4), with samples collected from within the euphotic zone and hypolimnion. In addition, the program could include monthly or more frequent sampling at major inflows and the lake's primary outflow (USGS gaging station 12415140, St. Joe River nr Chatcolet, Idaho; USGS gaging station 12413860, Coeur d'Alene River nr Harrison, Idaho; USGS gaging station 12417598, Spokane River at Lake Outlet at Coeur d'Alene, Idaho) to track changes in loads and in the lake's mass balance of selected constituents. Sampled constituents in the lake, at major inflows, and at the primary outflow could include algal biomass (cell counts), chlorophyll- $a$, total nitrogen, total phosphorus, total organic plus ammonia nitrogen, nitrite plus nitrate, dissolved ammonia, dissolved orthophosphate, major ions, trace metals including zinc, lead, and iron, total and dissolved organic carbon, suspended-sediment concentration, dissolved oxygen, water temperature, $\mathrm{pH}$, conductivity, and turbidity. Continuous data collection through installation of a long-term system for real-time measurements of wind speed and direction, chlorophyll- $a$, and depth profiles of temperature, $\mathrm{pH}$, conductivity, turbidity, dissolved oxygen, and zinc concentration in the lake would substantially enhance understanding of lake conditions and would allow better tracking and modeling of inflow plumes.

Data from both the 1991-92 and the 2004-06 USGS limnological studies have shown that littoral areas are statistically similar in water quality to pelagic areas and therefore do not need more extensive characterization. The inclusion of one or two representative littoral stations in a future monitoring program likely would be sufficient to track long-term changes in this area, unless land-use practices are suspected to cause near-shore alterations in water quality.

Some areas of the lake are prone to remobilization of dissolved metals from the bed sediments into the water column due to low dissolved oxygen concentrations during certain times of the year. This phenomenon could be tracked over time throughout the lake. In addition, the occurrence of nutrient sequestration by metals could be further investigated. For example, some phosphorus is bound to iron, resulting in decreased dissolved orthophosphate concentrations. A decrease in iron in the lake could result in increased dissolved orthophosphate. Sedimentation and burial rates of metals could be quantified to better understand the flux of particulate associated metals to sediments in various areas of the lake and to improve overall knowledge of metal transport, fate, and mass balance.

Although the St. Joe and Coeur d'Alene Rivers are major sources for nutrient loading to the lake, additional nutrient inputs from increased development along the shoreline and from ungaged tributaries have not been fully assessed over time. To effectively monitor and manage future nutrient inputs, this influence could be quantified using the ELCOMCAEDYM model and empirical variables and verified through point samples collected near suspected source locations and inflows.

\section{Summary}

Insights into the limnological functioning of Coeur d'Alene Lake were based on information developed from two large-scale limnological studies of the lake conducted during calendar years 1991-92 and water years 2004-06. The fate and transport of water and associated constituents following their delivery into a lake are determined by the interactions of a myriad of physical, chemical, and biological processes operating in the lake over a wide range of spatial and temporal scales.

Differences in hydrologic conditions were largely responsible for interannual differences in loads delivered into and discharged from Coeur d'Alene Lake because streamflow is a key factor in the calculation of constituent load. Overall, the lake is a sink for total nitrogen, total phosphorus, total cadmium, total lead, and total zinc loads. Total nitrogen inflow and outflow loads decreased in-between the 1991-92 and 2004-06 studies, primarily due to improvements in wastewater treatment processes and resulting decreases in total nitrogen concentrations in treatment plant effluent in major inflows to the lake. Total phosphorus inflow and outflow loads fluctuated with streamflow in both study periods, but loads relative to streamflow were higher in the 2004-06 study than the 1991-92 study because total phosphorus concentrations in gaged inflows were statistically higher in the latter study. 
Inflow trace-metal loads generally decreased between the 1991-92 and 2004-06 studies, but differences in sampling design and analytical reporting limits between the studies prevented a robust and accurate comparison of loads.

Comparison of water temperatures and water column transparency among the 4 years and five pelagic stations indicated no significant changes in water column heating and convective circulation. However, thermocline depths throughout the lake were highly variable during the years studied.

No significant changes in dissolved oxygen concentrations between study periods were noted at any stations. Concentrations were significantly lower in the hypolimnion than in the euphotic zone at all stations. The highest concentrations at each station were measured in winter in association with minimum water temperatures. Minimum concentrations were measured in the hypolimnion of each station during late summer or autumn as prolonged thermal stratification restricted mixing of the oxygenated upper water column with the hypolimnion.

Increased chlorophyll- $a$ and total phosphorus concentrations were measured throughout the lake in the 2004-06 study compared with the 1991-92 study. No significant change was detected in hypolimnetic dissolved inorganic nitrogen concentrations between study periods. Total zinc, total cadmium, and total lead concentrations decreased from the 1991-92 study to the 2004-06 study everywhere except at pelagic station 6 , where frequency of detection was low.

Large differences in median concentrations of dissolved inorganic nitrogen were measured in the euphotic zone and hypolimnion of the three deep stations (1, 3, and 4). These differences were attributable to several limnological processes, including seasonal inflow plume routing, isolation from winddriven circulation and associated hypolimnetic enrichment, phytoplanktonic assimilation during summer months, and benthic flux.

Median detected nitrogen-to-phosphorus ratios decreased from the 1991-92 study to the 2004-06 study. Whereas the lake was clearly phosphorus-limited in 1991-92, in 2004-06 the lake may have been much closer to the boundary value of 7.2 that separates nitrogen from phosphorus limitation. However, due to changes in analytical reporting limits over the two studies, the data are insufficiently certain to draw reliable conclusions with regard to limiting nutrients.

For both studies, the trophic state of the lake was classified as oligotrophic, or less productive, with regard to total phosphorus and chlorophyll- $a$ concentrations and as mesotrophic, or moderately productive, with regard to Secchidisc transparency depth.
The significant concentration gradients measured across the lake were:

- Dissolved inorganic nitrogen-gradient north and south radiating from central station 4 (high);

- Total phosphorus-gradient from south end (high) to north end (low);

- Total lead-gradient north and south radiating from central station 4 (high);

- Total zinc-gradient north and south radiating from central station 4 (high);

- Dissolved oxygen-gradient from north end (high) to south end (low); and

- Water column transparency-gradient from north end (high) to south end (low).

The southern end of the lake is a highly sensitive area that is subject to periodic anoxia, higher phosphorus concentrations, and higher turbidity. Although metals contamination is relatively low, the southern end of the lake is not completely isolated from metal-laden inflows from the Coeur d'Alene River or from wind-driven circulation of contaminated bed sediments from other parts of the lake. Higher lake productivity and hypolimnetic anoxia in this area will tend to remobilize any metals present in bed sediments.

Internal circulation from wind-generated waves and from changes in the thermocline is an important process for distribution of water-quality constituents throughout Coeur d'Alene Lake. Surficial distribution of trace metals throughout most of the lake, including the bays, is relatively uniform.

Even south of the Coeur d'Alene River mouth, lakebed sediments are contaminated with trace metals. Generally, no significant difference was detected in water quality between the pelagic euphotic zone and littoral zone (when comparing pelagic stations to closest littoral stations), indicating a relatively uniform surficial distribution of constituents across the lake.

The fate and transport of constituents such as nutrients, trace metals, and sediment in and occasionally through Coeur d'Alene Lake are highly dependent on inflow-plume routing of the two primary inflow sources, the Coeur d'Alene and St. Joe Rivers. Most riverine inflows move through the lake as overflow during summer, interflow during spring and autumn, and underflow during winter. However, shallow depths in the southern part of the lake may have allowed full-depth, convective circulation and muted the median-concentration difference between the euphotic zone and lower hypolimnion for most analytes. 
Benthic flux experiments showed that movements of dissolved metals, nutrients, and dissolved organic carbon out of lakebed sediments in the deep part of the lake, likely are due to molecular diffusion. This outward benthic flux of dissolved materials is in contrast to the sedimentation of the same materials to lake sediments when associated with particulate material, meaning that the sediments may be a source for dissolved metals and nutrients while still being a sink for the same constituents in particulate form. When anoxic conditions are not already present at the sedimentwater interface, the transition from oxic to anoxic conditions occurred in the top 1-5 cm of bed sediments. In the transition zone, the reduction of manganese and ferric oxyhydroxides can result in the release of trace metals in the dissolved phase. When anoxic conditions are present at the sedimentwater interface (such as in the southern area of the lake), no transition zone is present, and trace metals may be released right at the interface and would be available for transport by physical limnological processes.

\section{References Cited}

Baccini, P., 1985, Phosphate interactions at the sediment-water interface, in Stumm, Werner, ed., Chemical processes in lakes: New York, John Wiley and Sons, p. 189-205.

Balistrieri, L.S., 1998, Preliminary estimates of benthic fluxes of dissolved metals in Coeur d'Alene Lake, Idaho: U.S. Geological Survey Open-File Report 98-793, 40 p.

Berner, R.A., 1980, Early Diagenesis: Princeton, N.J., Princeton University Press, 241 p.

Brezonik, P.L., 1994, Chemical kinetics and process dynamics in aquatic systems: Boca Raton, Fla., Lewis Publishers, $754 \mathrm{p}$.

Britton, L.J., and Greeson, P.E., (eds.), 1989, Methods for collection and analysis of aquatic biological and microbiological samples: U.S. Geological Survey Techniques of Water-Resources Investigations, book 5, chapter A4, $685 \mathrm{p}$.

Brown, R.G., 1987, Errors in estimating ground-water components of hydrologic and phosphorus budgets of lakes, in Subitzky, Seymour, ed., Selected Papers in the Hydrologic Sciences: U.S. Geological Survey Water-Supply Paper 2310-D, p. 53-64.

CH2M Hill Inc., and URS Corp., 2001, Final ecological risk assessment-Coeur d'Alene Basin Remedial Investigation/ Feasibility Study: Prepared for U.S. Environmental Protection Agency, Region 10, Seattle, Wash., CH2M Hill, Inc., and URS Corp., 63 p.
Childress, C.J.O., Foreman, W.T., Connor, B.F., and Maloney, T.J., 1999, New reporting procedures based on long-term method detection levels and some considerations for interpretations of water-quality data provided by the U.S. Geological Survey's National Water Quality Laboratory: U.S. Geological Survey Open-File Report 99-193, 19 p.

Fischer, H.B., List, E.J., Koh, R.C.Y., Imberger, J, and Brooks, N.H., 1979, Mixing in inland and coastal waters: New York, Academic Press, 483 p.

Froelich, P.N., Klinkhammer, G.P., Bender, M.L., Luedtke, N.A., Heath, G.R., Cullen, D., Dauphin, P., Hammond, D., Hartman, B., and Maynard, V., 1979, Early oxidation of organic matter in pelagic sediments of the eastern equatorial Atlantic - suboxic diagenesis: Geochimica et Cosmochimica Acta, v. 43, p. 1075-1090.

Hallock, D.D., and Falter, C.M., 1987, Powerboat engine discharges as a nutrient source in high use lakes, in Lake and Reservoir Management: Washington, D.C., North American Lake Management Society, v. 3, p. 172-180.

Harenberg, W.A., Jones, M.L., O’Dell, I., Brennan, T.S., Lehmann, A.K., and Tungate, A.M., 1992, Water resources data, Idaho, water year 1991: U.S. Geological Survey Water-Data Report ID-91-2, 357 p.

Harenberg, W.A., Jones, M.L., O’Dell, I., Brennan, T.S., Lehmann, A.K., and Tungate, A.M., 1993, Water resources data, Idaho, water year 1992: U.S. Geological Survey Water-Data Report ID-92-2, 431 p.

Harrington, I.M., Laforce, M.I., Rember, W.C., Fendorf, S.E., and Rosenzweig, R.F., 1998, Phase associations and mobilization of iron and trace elements in Coeur d'Alene Lake, Idaho: Environmental Science and Technology, v. 32, p. 650-656.

Helsel, D.R., 2005, More than obvious: better methods for interpreting nondetect data: Environmental Science and Technology, v. 39, iss. 20, p. 419A-423A.

Helsel, D.R., and Hirsch, R.M., 2002, Statistical methods in water resources-Hydrologic analysis and interpretation: U.S. Geological Survey Techniques of Water-Resources Investigations, book 4, chap., A3, 510 p.

Hem, J.D., 1985, Study and interpretation of the chemical characteristics of natural water: U.S. Geological Survey Water-Supply Paper 2254, 263 p, 3 pls.

Hintze, J., 2006, NCSS, PASS, and GESS statistical software: Kaysville, Utah, NCSS, accessed April 20, 2007, at http:// www.ncss.com 
Hipsey, M.R., Alexander, R., and Dallimore, C.J., 2006, Simulation model to evaluate Coeur d'Alene Lake's response to watershed remediation, Vol. 2, Water-quality modeling using ELCOM-CAEDYM: University of Western Australia, Centre for Water Research, Document No. WP2132MH, Draft, 80 p.

Horowitz, A.J., Elrick, K.A., and Cook, R.B., 1993, Effect of mining and related activities on the sediment trace element geochemistry of Lake Coeur d'Alene, Idaho, USA, Part I-surface sediments: Hydrological Processes, v.7, iss. 4, p. 403-423.

Horowitz, A.J., Elrick, K.A., Robbins, J.A., and Cook, R.B., 1995a, Effect of mining and related activities on the sediment trace element geochemistry of Lake Coeur d'Alene, Idaho, USA, Part II—-subsurface sediments: Hydrological Processes, v. 9, iss. 1, p. 35-54.

Horowitz, A.J., Elrick, K.A., Robbins, J.A., and Cook, R.B., 1995b, A summary of the effects of mining and related activities on the sediment-trace element geochemistry of Lake Coeur d'Alene, Idaho, USA: Journal of Geochemical Exploration, v.52, p. 135-144.

Horowitz, A.J., Elrick, K.A., Robbins, J.A., and Cook, R.B., 2001, The effect of mining and related activities on the sediment-trace element geochemistry of Lake Coeur d'Alene, Idaho, USA, Part III-downstream effects: the Spokane River Basin: Hydrological Processes, v.15, iss. 5, p. 855-875.

Idaho Department of Environmental Quality and Coeur d'Alene Tribe, 2008, Draft Coeur d'Alene Lake management plan, 161 p., accessed August 11, 2008 at http://www.cdatribe.org/docs/2008draftplan.pdf

Jones, B.F., and Bowser, C.J, 1978, The mineralogy and related chemistry of lake sediments, in Lerman, Abraham, ed., Lakes - chemistry, geology, physics: New York, Springer-Verlag, p. 179-235.

Kuwabara, J.S., Berelson, W.M., Balistrieri, L.S., Woods, P.F., Topping, B.R., Steding, D.J., and Krabbenhoft, D.P., 2000, Benthic flux of metals and nutrients into the water column of Lake Coeur d'Alene, Idaho-report of an August 1999 pilot study: U.S. Geological Survey Water-Resources Investigations Report 00-4132, variously paged.

Kuwabara, J.S., Carter, J.L., Topping, B.R., Fend, S.V., Woods, P.F., Berelson, W.M., and Balistrieri, L.S., 2003, Importance of sediment-water interactions in Coeur d'Alene Lake, Idaho, USA - management implications: Environmental Management, v. 32, no. 3, p. 348-359.
Kuwabara, J.S., Topping, B.R., Woods, P.F., Carter, J.L., and Hager, S.W., 2006, Interactive effects of dissolved zinc and orthophosphate on phytoplankton from Coeur d’Alene Lake, Idaho: U.S. Geological Survey Scientific Investigations Report 2006-5091, 26 p.

Luther, G.W., III, Brendel, P.J., Lewis, B.L., Sundby, B., Lefrancois, L., Silverberg, N., and Nuzzio, D.B., 1998, Simultaneous measurement of $\mathrm{O}_{2}, \mathrm{Mn}, \mathrm{Fe}, \mathrm{I}^{-}$, and $\mathrm{S}(-\mathrm{II})$ in marine pore waters with a solid-state voltammetric microelectrode: Limnology and Oceanography, v. 43, no. 2, p. 325-333.

National Atmospheric Deposition Program, 1991, NADP/ NTN Annual data summary-precipitation chemistry in the United States, 1990: Fort Collins, Colorado State University, Natural Resource Ecology Laboratory, 475 p.

Pedersen, T.F., and Losher, A.J., 1988, Diagenetic processes in aquatic mine tailings deposits in British Columbia in Salomons, W., and Forstner, U., eds., Chemistry and Biology of Solid Waste_-Dredged Material and Mine Tailings: Springer-Verlag, p. 238-258.

Runkel, R.L., Crawford, C.F., and Cohn, T.A., 2004, Load estimator (LOADEST) — a FORTRAN program for estimating constituent loads in streams and rivers: U.S. Geological Survey Techniques and Methods, book 4, chap. A5, 69 p.

Ryding, S.O., and Rast, W., 1989, Control of eutrophication in lakes and reservoirs, v. 1 of Programme on man and the biosphere: Cambridge University Press, 295 p.

Santschi, P., Höhener, P., Benoit, G., and Buchholtz-ten Brink, M., 1990, Chemical processes at the sediment-water interface: Marine Chemistry, v. 30, p. 269-315.

Stanford, J.A., Stuart, T.J., and Ellis, B.K., 1983, Limnology of Flathead Lake: U.S. Environmental Protection Agency, Final Report, Flathead River Basin Environmental Impact Study [not paged].

URS Greiner, Inc., and CH2M Hill, Inc., 2001, Remedial investigation report, Coeur d'Alene Basin remedial investigation/feasibility study, v. 4, part 5, Coeur d'Alene Lake-Response action contract no. 68-W-98-228, prepared for U.S. Environmental Protection Agency, Region 10, variously paged.

U.S. Census Bureau, 2000, Annual time series of population estimates, 1991 to 1999, and 1990 census population for incorporated places, accessed July 15, 2008, at http://www. census.gov/popest/archives/1990s/ 
U.S. Environmental Protection Agency, 1977, Report on Coeur d'Alene Lake, Benewah and Kootenai Counties, Idaho: Washington, D.C., U.S. Environmental Protection Agency, National Eutrophication Survey Working Paper no. 778, 20 p., 5 apps.

U.S. Environmental Protection Agency, 2002, The Bunker Hill Mining and Metallurgical Complex-Operable Unit 3, Record of Decision: Seattle, Wash., U.S. Environmental Protection Agency, Region 10, 507 p.

U.S. Geological Survey, 2007, Annual water data report for Idaho, water year 2006, accessed March 20, 2007, at http:// web10capp.er.usgs.gov

U.S. Geological Survey National Water Quality Laboratory, 2000, Implementation of a water-quality analytical method for the fluorometric determination of chlorophyll a and pheophytin a in periphyton and phytoplankton: National Water Quality Laboratory Policy Memorandum 2000.05, $1 \mathrm{p}$.

Walker, W.W., 1987, Empirical methods for predicting eutrophication in impoundments, report 4, phase III, applications manual: U.S. Army Corps of Engineers Technical Report E-81-9, variously paged.

Walker, W.W., 1996, Simplified procedures for eutrophication assessment and prediction: user manual: U.S. Army Corps of Engineers Instruction Report W-96-2, 235 p.
Wetzel, R.G., 1983, Limnology, 2nd ed.: Philadelphia, Saunders College Publishing, 858 p.

Winowiecki, L., 2002, Geochemical cycling of heavy metals in the sediment of Lake Coeur d'Alene, Idaho: Moscow, University of Idaho, M.S. thesis, 196 p.

Woods, P.F., 1989, Hypolimnetic concentrations of dissolved oxygen, nutrients, and trace elements in Coeur d'Alene Lake, Idaho: U.S. Geological Survey Water-Resources Investigations Report 89-4032, 56 p.

Woods, P.F., 2004, Role of limnological processes in fate and transport of nitrogen and phosphorus loads delivered into Coeur d'Alene Lake and Lake Pend Oreille, Idaho, and Flathead Lake, Montana: U.S. Geological Survey Professional Paper 1682, 44 p.

Woods, P.F., and Beckwith, M.A., 1997, Nutrient and traceelement enrichment of Coeur d'Alene Lake, Idaho: U.S. Geological Survey Water-Supply Paper 2485, 93 p.

Woods, P.F., and Berenbrock, C., 1994, Bathymetric map of Coeur d'Alene Lake, Idaho: U.S. Geological Survey WaterResources Investigations Report 94-4119, 1 sheet. 
This page intentionally left blank. 
Appendix A. Analytical Data for Samples Collected at Pelagic and Littoral Stations in Coeur d'Alene Lake, Calendar Years 1991-92

Data are available for download at http://pubs.usgs.gov/sir//2008/5168/AppendixA.xls

Appendix B. Analytical Data for Samples Collected at Pelagic and Littoral Stations in Coeur d'Alene Lake, Water Years 2004-06

Data are available for download at http://pubs.usgs.gov/sir//2008/5168/AppendixB.xls

Appendix C. Selected Analytical Data for Quality-Control Samples Collected in Coeur d'Alene Lake, Water Years 2004-06

Data are available for download at http://pubs.usgs.gov/sir//2008/5168/AppendixC.xls 
This page intentionally left blank. 
Manuscript approved for publication, September 15, 2008

Prepared by the USGS Publishing Network

Bill Gibbs

Debra Grillo

Bobbie Jo Richey

Sharon Wahlstrom

For more information concerning the research in this report, contact the

Director, Idaho Water Science Center

U.S. Geological Survey, 230 Collins Road

Boise, Idaho 83702

http://id.water.usgs.gov 
